\title{
Controlling the Oxidation State of Cu Electrode and Reaction Intermediates for Electrochemical $\mathrm{CO}_{2}$ Reduction to Ethylene
}

\author{
Tsu-Chin $\mathrm{Chou}^{1}$, Chiao-Chun Chang ${ }^{1}$, Hung-Ling $\mathrm{Yu}^{1}$, Wen-Yueh $\mathrm{Yu}^{2}$, Chung-Li \\ Dong ${ }^{3}$, Juan-Jesús Velasco-Vélez ${ }^{4}$, Cheng-Hao Chuang ${ }^{3}$, Li-Chyong Chen ${ }^{1,5}$, Jyh-Fu \\ Lee $^{6}$, Jin-Ming Chen ${ }^{6}$ and Heng-Liang $\mathrm{Wu}^{1,5^{*}}$
}

1. Center for Condensed Matter Sciences, National Taiwan University, Taipei 10617, Taiwan

2. Department of Chemical Engineering, National Taiwan University, Taipei 10617, Taiwan

3. Department of Physics, Tamkang University, New Taipei City 25137, Taiwan.

4. Department of Inorganic Chemistry, Fritz-Haber-Institut der Max-PlanckGesellschaft, Berlin 14195, Germany

5. Center of Atomic Initiative for New Materials, National Taiwan University, Taipei 10617, Taiwan

6. National Synchrotron Radiation Research Center, Hsinchu, 30076, Taiwan

*Corresponding author E-mail: hengliangwu@,ntu.edu.tw

KEYWORDS: Electrochemical $\mathrm{CO}_{2}$ reduction, in situ SEIRAS, in situ soft X-ray absorption spectroscopy, $\mathrm{CO}$ intermediates, Oxidation state of $\mathrm{Cu}$ surface. 


\section{Abstract:}

Understanding the role of oxidation state of $\mathrm{Cu}$ surface and surface-adsorbed intermediate species in electrochemical $\mathrm{CO}_{2}$ reduction is crucial for the development of selective $\mathrm{CO}_{2}$-to-fuel electrocatalysts. In this study, the electrochemical $\mathrm{CO}_{2}$ reduction mechanism over the $\mathrm{Cu}$ catalysts with various oxidation states was studied by using in situ surface-enhanced infrared absorption spectroscopy (SEIRAS), in situ soft X-ray absorption spectroscopy ( $\mathrm{Cu}$ L-edge) and on-line gas chromatography measurements. The atop-adsorbed $\mathrm{CO}\left(\mathrm{CO}_{\text {atop }}\right)$ intermediate is obtained on the electrodeposited $\mathrm{Cu}$ surface which primarily has the oxidation state of $\mathrm{Cu}(\mathrm{I}) . \mathrm{CO}_{\text {atop }}$ is further reduced, followed by the formation of $\mathrm{C}_{1}$ product such as $\mathrm{CH}_{4}$. The residual bridge-adsorbed $\mathrm{CO}\left(\mathrm{CO}_{\text {bridge}}\right)$ is formed on the as-prepared $\mathrm{Cu}$ surface with $\mathrm{Cu}(0)$ which inhibits hydrocarbon formation. In contrast, the $\mathrm{CV}$-treated $\mathrm{Cu}$ electrode prepared by oxidizing the as-prepared $\mathrm{Cu}$ surface contains different amount of $\mathrm{Cu}(\mathrm{I})$ and $\mathrm{Cu}(0)$ states. The major theme of this work is that in situ SEIRAS results show the coexistence of $\mathrm{CO}_{\text {atop }}$ and $\mathrm{CO}_{\text {bridge }}$ as the reaction intermediates during $\mathrm{CO}_{2}$ reduction and the selectivity of $\mathrm{CO}_{2}$-to-ethylene conversion is further enhanced in the $\mathrm{CV}$-treated $\mathrm{Cu}$ electrode. The $\mathrm{Cu}$ catalysts modulated by electrochemical method exhibit different oxidation states and reaction intermediates as well as the electrocatalytic properties. 


\section{Introduction}

Electrochemical $\mathrm{CO}_{2}$ reduction reaction $(\mathrm{CO} 2 \mathrm{RR})$ is a promising route to convert $\mathrm{CO}_{2}$ into valuable hydrocarbon fuels and chemical feedstock for sustainable carbon cycles. ${ }^{1-2}$ The catalysts capable of electrochemically reducing $\mathrm{CO}_{2}$ still suffer from many challenges such as short catalyst lifetime, high overpotential, low Faradic efficiencies (FEs) and poor product selectivity, mainly due to the multiple number of proton-coupled electron transfer steps. ${ }^{3}$ The development of efficient and selective catalysts for CO2RR has attracted tremendous attentions. ${ }^{4-6}$ Among all transition metal catalysts explored for $\mathrm{CO} 2 \mathrm{RR}$, copper $(\mathrm{Cu})$ is the promising catalyst to produce hydrocarbons including methane $\left(\mathrm{CH}_{4}\right)$ and ethylene $\left(\mathrm{C}_{2} \mathrm{H}_{4}\right) \cdot{ }^{7-8}$ However, bulk $\mathrm{Cu}$ electrode exhibits high overpotentials and a lack of product selectivity. Furthermore, metallic $\mathrm{Cu}$ is oxidized under air easily.

Various strategies have been used to enhance the performance of CO2RR performance by modulating the catalytic structure and physical properties of electrolyte as well as the oxidation state of $\mathrm{Cu}$ catalyst. ${ }^{4,6,9-14}$ For instance, $\mathrm{Cu}$ nanostructures with different particle size, particle morphology and surface area exert a great impact on the catalytic properties. ${ }^{9-14} \mathrm{C}_{2}$ products are formed over the $\mathrm{Cu}(100)$ electrode while $\mathrm{Cu}(111)$ is effective to produce $\mathrm{C}_{1}$ products, ${ }^{7-8}$ suggesting that the facet of $\mathrm{Cu}$ catalyst results in different $\mathrm{CO}_{2}$ reduction mechanisms. The physical properties of electrolyte 
also play crucial roles in the product selectivity over the $\mathrm{Cu}$ electrodes. The electrolyte with different proton concentrations ( $\mathrm{pH}$ values) influences the protonation step for the production of $\mathrm{COOH}$ in $\mathrm{CO} 2 \mathrm{RR}^{5}$

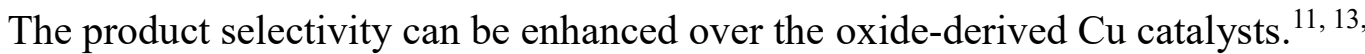
15-18 These Cu-based materials synthesized by the reduction of thermally oxidized $\mathrm{Cu},{ }^{19}$ electrodeposited $\mathrm{Cu}_{2} \mathrm{O},{ }^{20}$ and oxygen plasma treated $\mathrm{Cu}$ catalysts ${ }^{13,18}$ display a higher current density, formation of $\mathrm{CO}$ at low overpotentials, and improved FEs of $\mathrm{C}_{2} \mathrm{H}_{4} .{ }^{18}$ The effect of the oxide-derived $\mathrm{Cu}$ catalysts on the product selectivity has been studied. The grain boundaries in oxide-derived $\mathrm{Cu}$ could provide unique surface sites. ${ }^{21-22}$ Reske et al. showed that the low-coordinated atoms formed on the surface of the catalyst behave as the active sites during the oxide reduction. ${ }^{9} \mathrm{The}^{\mathrm{C}} \mathrm{Cu}^{\delta+}$ sites remained on the oxide-derived $\mathrm{Cu}$ surface have also been suggested to be the active sites for $\mathrm{CO} 2 \mathrm{RR} .{ }^{18}$, ${ }^{20}$ To further examine the effect of $\mathrm{Cu}(\mathrm{I})$ on the $\mathrm{CO}_{2}$ reduction mechanism, previous studies reported that $\mathrm{Cu}(\mathrm{I})$ sites alone do not improve the efficiencies of CO2RR. The DFT calculations proposed that the synergy between active surface $\mathrm{Cu}(\mathrm{I})$ and $\mathrm{Cu}(0)$ regions resulted in the adsorption of $\mathrm{CO}$ intermediates on different reaction sites is responsible for improving the $\mathrm{CO}$ dimerization. ${ }^{23}$ However, experimental evidences are needed for the proposed model.

The surface-adsorbed CO intermediates are formed during CO2RR, followed by 
the dimerization process of $\mathrm{CO}$ intermediates, which are generally regarded as the control step for $\mathrm{CH}_{4}$ and $\mathrm{C}_{2} \mathrm{H}_{4}$ formation. ${ }^{5}$ In situ surface-enhanced infrared absorption spectroscopy (SEIRAS) is a powerful tool for examining the adsorbed intermediates on $\mathrm{Cu}$ catalysts. ${ }^{24-28}$ As a result of various adsorption sites for $\mathrm{CO}$ molecule, previous studies on $\mathrm{Cu}$ surface mainly focus on the dynamic evolution of adsorbed $\mathrm{CO}$ and the formation of adsorbed $\mathrm{CO}$ including atop-adsorbed $\mathrm{CO}$ and bridge-adsorbed $\mathrm{CO}{ }^{27,29-}$ ${ }^{30}$ The atop-adsorbed $\mathrm{CO}$ has been recognized as the common intermediate on $\mathrm{Cu}$ surface $^{24-28}$ and the atop-adsorbed $\mathrm{CO}$ alone is observed in a variety of experimental conditions such as $\mathrm{pH}$ value of electrolyte, ${ }^{31}$ and partial pressure of $\mathrm{CO}_{2}$ (or $\left.\mathrm{CO}\right){ }^{25}$ These $\mathrm{Cu}$ electrodes are electrochemically deposited on $\mathrm{Au}$ substrate and chemically deposited on Si prism. ${ }^{26,32}$ In contrast, Gunathunge et al. showed that both atopadsorbed $\mathrm{CO}$ and bridge-adsorbed $\mathrm{CO}$ can be formed on the chemically deposited $\mathrm{Cu}$ thin film in alkaline $\mathrm{pH}$ electrolyte and the bridge-adsorbed $\mathrm{CO}$ is inactive during CO2RR ${ }^{27}$ In addition, these $\mathrm{CO}$ intermediates are also observed in electropolished $\mathrm{Cu}$ electrode,${ }^{30}$ suggesting that controlling the formation of atop-adsorbed $\mathrm{CO}$ and bridgeadsorbed $\mathrm{CO}$ on $\mathrm{Cu}$ surface is still challenging. The $\mathrm{CO}_{2}$ reduction mechanism behind various $\mathrm{Cu}$ electrodes is unclear due to the lack of understanding of oxidation state of $\mathrm{Cu}$ accompanied with the formation of $\mathrm{CO}$ intermediates.

In this study, we used in situ soft X-ray absorption spectroscopy, in situ SEIRAS 
and on-line gas chromatography (GC) measurements to study the oxidation state of $\mathrm{Cu}$, surface-adsorbed intermediates and final products during CO2RR. By combining these in situ techniques, we are able to provide the complementary information and elucidate the reaction pathways about the electrochemical $\mathrm{CO}_{2}$ reduction mechanism on $\mathrm{Cu}$ electrodes. Our results show that the amount of $\mathrm{Cu}(\mathrm{I})$ and $\mathrm{Cu}(0)$ oxidation states in $\mathrm{Cu}$ catalysts can be modulated by the electrochemical method. The coexistence of atopadsorbed $\mathrm{CO}$ and bridge-adsorbed $\mathrm{CO}$ on the $\mathrm{CV}$-treated $\mathrm{Cu}$ surface is observed during

$\mathrm{CO}_{2}$ reduction. The different $\mathrm{CO}$ species formed on the $\mathrm{Cu}$ electrodes could play crucial roles in the $\mathrm{CO}_{2}$ reduction mechanism. The prepared $\mathrm{Cu}$ electrodes with specific oxidation states influence the formation of $\mathrm{CO}$ intermediates and product selectivity during CO2RR.

\section{Experimental Section}

\section{Chemicals and electrolyte}

$\mathrm{KHCO}_{3}(\geq 99.8 \%)$ and $\mathrm{CuSO}_{4}(\geq 99.8 \%)$ were purchased from Sigma Aldrich. Ultrapure $\mathrm{H}_{2} \mathrm{SO}_{4}(98 \%)$ and $\mathrm{CO}_{2}(\geq 99.995 \%)$ were purchased from Kanto Chemical Co. and FMI gas Taiwan, respectively. All chemicals were used as received without further purification. Millipore triple-distilled water (18.2 M $\Omega$ ) was used to prepare solutions. The $0.1 \mathrm{M} \mathrm{CO}_{2}$-saturated $\mathrm{KHCO}_{3}$ electrolyte with a $\mathrm{pH}$ value of 6.8 is prepared by purging $\mathrm{CO}_{2}$ in $0.1 \mathrm{M} \mathrm{KHCO}_{3}$ electrolyte for $60 \mathrm{~min}$. 


\section{Preparation of as-prepared $\mathrm{Cu}$ electrodes}

$\mathrm{A} \mathrm{Cu}$ thin film with the thickness of ca. $36 \mathrm{~nm}$ was prepared using physical vapor deposition (PVD) on the reflecting plane of hemicylindrical Si prism or Si wafer by a home-built ion beam sputtering system and then transferred into the electrochemical cell immediately for the measurements to avoid the $\mathrm{Cu}$ oxidation. The thickness of asprepared polycrystalline $\mathrm{Cu}$ was measured by atomic force microscopy (AFM, Figure S1). A high purity $\mathrm{Cu}(99.998 \%)$ purchased from Gredmann Taiwan Ltd. is used as the sputtering target and $\mathrm{Ar}^{+}$is serving as the bombardment source. The deposition rate and thickness are monitored by using a quartz crystal microbalance. The as-prepared $\mathrm{Cu}$ electrode was deposited at a deposition rate of $0.4 \AA \mathrm{s}^{-1}$ in the present study.

\section{Preparation of cyclic voltammetry (CV)-treated $\mathrm{Cu}$ electrodes}

$\mathrm{CV}$-treated $\mathrm{Cu}$ electrode is prepared by cycling the as-prepared $\mathrm{Cu}$ electrode in a potential region of 0.55 to $-0.3 \mathrm{~V}$. All potentials in the present study are reported with respect to the reversible hydrogen electrode (RHE).

\section{Preparation of electrodeposited $\mathrm{Cu}$ on Au electrode}

A thin $\mathrm{Au}$ film with a thickness of $\sim 10 \mathrm{~nm}$ is prepared on Si prism using electroless deposition described previously. ${ }^{24,26,33}$ The Au film was cycled in an Ar-saturated 0.1 $\mathrm{M} \mathrm{H}_{2} \mathrm{SO}_{4}$ solution at a scan rate of $50 \mathrm{mV} \mathrm{s}^{-1}$ between 0.1 and $1.6 \mathrm{~V}$ (vs. RHE) to clean Au surface. ${ }^{34}$ The prepared Au film was then transferred in a solution of $5 \mathrm{mM} \mathrm{CuSO}_{4}$ 
and $0.1 \mathrm{M} \mathrm{H}_{2} \mathrm{SO}_{4}$ for the electrochemical deposition process. $\mathrm{Cu}$ film $(\sim 50 \mathrm{~nm})$ was then electrochemically deposited on Au film at $0.1 \mathrm{~V}$ (vs. RHE) for $600 \mathrm{~s} .{ }^{26}$ Figure S2 shows the AFM image and $\mathrm{CV}$ of electrodeposited $\mathrm{Cu}$.

In situ surface-enhanced infrared absorption spectroscopy and electrochemical

\section{measurements}

In situ surface-enhanced infrared absorption spectroscopy (SEIRAS) was recorded in the home-built reflection accessory with external reflection configuration using a Thermo Nicolet 6700 FTIR spectrometer equipped with a $\mathrm{HgCdTe}$ (MCT) detector. ${ }^{35}$ All spectra were acquired with a spectral resolution of $4 \mathrm{~cm}^{-1}$. The typical acquisition time was $30 \mathrm{~s}$ per spectrum. The time-dependent measurement takes $12 \mathrm{~s}$ per spectrum. For spectroelectrochemical measurements, the spectrometer was coupled with the electrochemical workstation (ZENNIUM E, Zahner). The working electrodes are PVD $\mathrm{Cu}$ or electrodeposited $\mathrm{Cu}$ on $\mathrm{Au}$. The counter and reference electrodes are graphite rod and $\mathrm{Ag} / \mathrm{AgCl}$ electrode, respectively. The graphite counter electrode is used to avoid any possible contaminations from $\mathrm{Pt}$ electrode. ${ }^{26}$ The electrolytes used in all spectroelectrochemical measurements were $0.1 \mathrm{M} \mathrm{CO}_{2}$-saturated $\mathrm{KHCO}_{3}(\mathrm{pH}=6.8)$. The CV for in situ SEIRAS measurements was performed at a scan rate of $2 \mathrm{mV} \mathrm{s}^{-1}$. Figure S3 shows the cell configuration of in situ SEIRAS measurements. More details for in situ SEIRAS are described elsewhere. ${ }^{36}$ 


\section{X-ray absorption spectroscopy measurements}

In situ soft X-ray absorption spectroscopy was used to monitor the changes in oxidation state of $\mathrm{Cu}$ surface during reactions. In situ and ex situ $\mathrm{Cu} \mathrm{L}_{3}$-edge X-ray absorption spectroscopy measurements were conducted with total fluorescence yield (TFY) mode and total electron yield (TEY) mode, respectively, in Taiwan Light Source beam-line 20A end station (National Synchrotron Radiation Research Center, Taiwan).

A flow type spectroelectrochemical cell was used for in situ soft X-ray absorption spectroscopy measurements as described in previous literature ${ }^{37}$ First, we deposit $\mathrm{Cu}$ thin film (PVD Cu) with the thickness of $\sim 36 \mathrm{~nm}$ on a $\mathrm{SiN}_{\mathrm{x}} \mathrm{X}$-ray transparent window with underlying adhesion layers of $\mathrm{Cr}(2 \mathrm{~nm})$ and $\mathrm{Au}(5 \mathrm{~nm})$ served as working electrodes, and two Pt wires were conducted as counter and reference electrodes. X-ray absorption spectra were collected as a function of applied potential during cyclic voltammetry $(\mathrm{CV})$ at a scan rate of $2 \mathrm{mV} \mathrm{s}^{-1}$, which yields a potential resolution of $\sim 120$ $\mathrm{mV}$ owing to an acquisition time of $60 \mathrm{~s}$ per spectrum. Figure $\mathrm{S} 4$ shows the cell configuration of in situ soft X-ray absorption spectroscopy measurements. Since the $\mathrm{Cu}$ electrodes can be easily oxidized under air conditions, all the prepared $\mathrm{Cu}$ electrodes were kept in a vacuum chamber and transferred to a chamber filled with Argon before the soft X-ray absorption spectroscopy measurements to avoid the $\mathrm{Cu}$ oxidation.

In situ $\mathrm{Cu} \mathrm{K}$-edge X-ray absorption spectroscopy including extended X-ray 
absorption fine-structure spectroscopy (EXAFS) was conducted in Taiwan Light Source beam-line 17A end station (National Synchrotron Radiation Research Center,

Taiwan). All the spectra were further analyzed with Athena software.

\section{Atomic force microscopy}

The surface morphology of $\mathrm{Cu}$ was imaged by atomic force microscopy (AFM, Innova, Bruker) with tapping mode by using a $\mathrm{Si}_{3} \mathrm{~N}_{4}$ cantilever (TESPA, radius of $8 \mathrm{~nm}$, spring constant of $42 \mathrm{~N} \mathrm{~m}^{-1}$, resonance frequency of $320 \mathrm{kHz}$, Bruker). All AFM studies were conducted on Si prisms with a hemicylindrical holder.

\section{High performance liquid chromatography and on-line gas chromatography}

\section{measurements}

Gas product analysis was carried out using home-built on-line gas chromatography (GC) system with pulsed discharge helium ionization detector. (Agilent 7890, USA) The electrochemical cell coupled to the GC system was used to monitor the gas products formed during $\mathrm{CO}_{2}$ reduction. Figure $\mathrm{S} 5$ shows the cell configuration for online GC measurements. High performance liquid chromatography (HPLC) with photometric diode array detector (JASCO, Japan) was used to analyze the liquid products such as formic acid $(\mathrm{HCOOH})$. The reaction potential was held for 5 min to accumulate enough product for each GC/HPLC measurement. Each measurement takes 20 min. Both PVD $\mathrm{Cu}$ electrode and electropolished $\mathrm{Cu}$ foil were used to study the 
effect of $\mathrm{CV}$ treatment on the product distributions. The electropolished $\mathrm{Cu}$ foil was held at $-1 \mathrm{~V}$ for $60 \mathrm{~min}$ to form the as-prepared $\mathrm{Cu}$ foil with the oxidation state of $\mathrm{Cu}(0)$ in the $\mathrm{CO}_{2}$-saturated $0.1 \mathrm{M} \mathrm{KHCO}_{3}$ electrolyte. The calculation of Faradaic efficiencies (FEs) for gas and liquid products is shown in supporting information.

\section{Results and Discussion:}
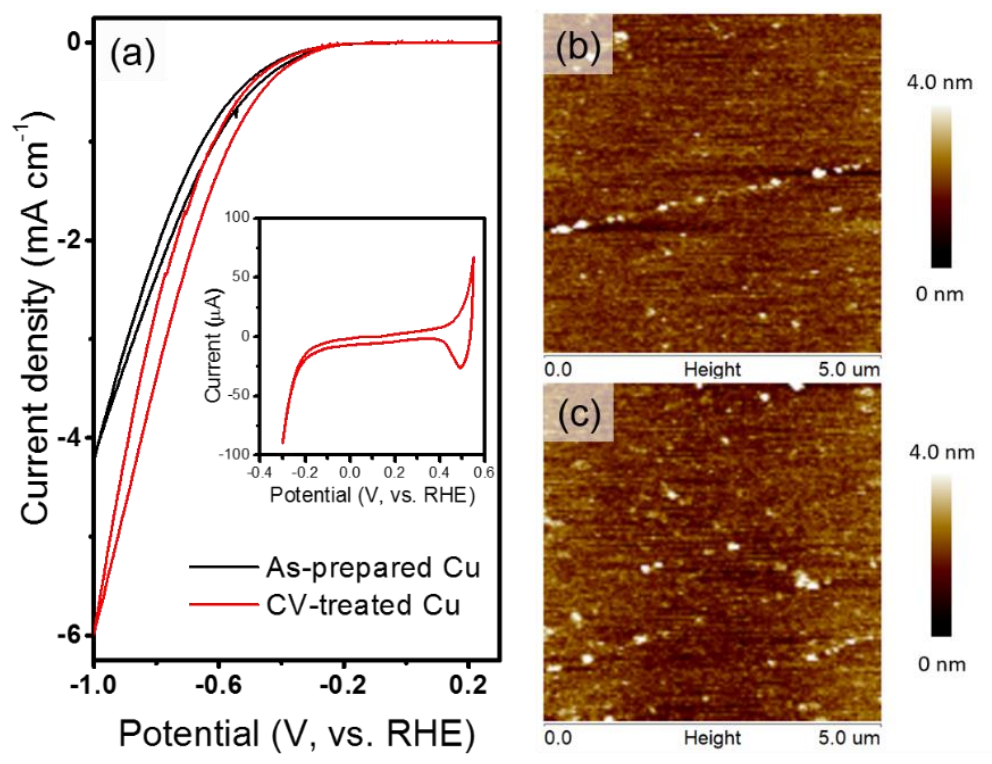

Figure 1. (a) Cyclic voltammetry (CV) of as-prepared $\mathrm{Cu}$ electrode and $\mathrm{CV}$-treated $\mathrm{Cu}$ electrode with $\mathrm{CO}_{2}$-saturated $0.1 \mathrm{M} \mathrm{KHCO}_{3}$ electrolyte at a scan rate of $10 \mathrm{mV} \mathrm{s}^{-1}$ in the potential range of 0.25 and $-1 \mathrm{~V}$. The inset in Figure 1a: CV curve of as-prepared $\mathrm{Cu}$ electrode obtained in a potential range of -0.3 to $0.55 \mathrm{~V}$. AFM images of the surface morphology of (b) as-prepared and (c) CV-treated Cu electrode (after three CV-treated cycles). The scanned area of AFM images is $5 \mu \mathrm{m} \times 5 \mu \mathrm{m}$.

Figure 1a shows the cyclic voltammetry $(\mathrm{CV})$ of as-prepared $\mathrm{Cu}$ electrode and $\mathrm{CV}$ treated $\mathrm{Cu}$ electrode with $\mathrm{CO}_{2}$-saturated $0.1 \mathrm{M} \mathrm{KHCO}_{3}$ electrolyte at a scan rate of 10 $\mathrm{mV} \mathrm{s}^{-1}$ in the potential range of 0.25 to $-1 \mathrm{~V}$. The as-prepared $\mathrm{Cu}$ electrode is cycled in the potential region of 0.55 to $-0.3 \mathrm{~V}$ (inset in figure 1a). After three cycles, $\mathrm{CV}$-treated 
$\mathrm{Cu}$ electrode is prepared and exhibits a larger reduction current than that of as-prepared

$\mathrm{Cu}$ electrode in $\mathrm{CO}_{2}$-saturated $0.1 \mathrm{M} \mathrm{KHCO}_{3}$ electrolyte. Figure $1 \mathrm{~b}$-c shows the AFM images of the surface morphology of (b) as-prepared and (c) CV-treated $\mathrm{Cu}$ electrode (after three CV-treated cycles) with a scanned area of $5 \mu \mathrm{m} \times 5 \mu \mathrm{m}$. The surface roughness of $\mathrm{CV}$-treated $\mathrm{Cu}$ electrode is similar to that of as-prepared $\mathrm{Cu}$ surface $\left(\mathrm{R}_{\mathrm{q}}=\right.$ $0.44 \pm 0.05 \mathrm{~nm}$ for as-prepared $\mathrm{Cu}$ surface and $\mathrm{R}_{\mathrm{q}}=0.50 \pm 0.04 \mathrm{~nm}$ for $\mathrm{CV}$-treated $\mathrm{Cu}$ surface), suggesting that the changes in surface area of $\mathrm{Cu}$ electrode have less contribution on the larger reduction current of $\mathrm{CV}$ treated $\mathrm{Cu}$ surface during $\mathrm{CO}_{2}$ reduction. Meanwhile, the double layer capacitances obtained from $\mathrm{Cu}$ electrodes suggest less changes in surface area of as-prepared $\mathrm{Cu}$ after three $\mathrm{CV}$-treated cycles (Figure S6).
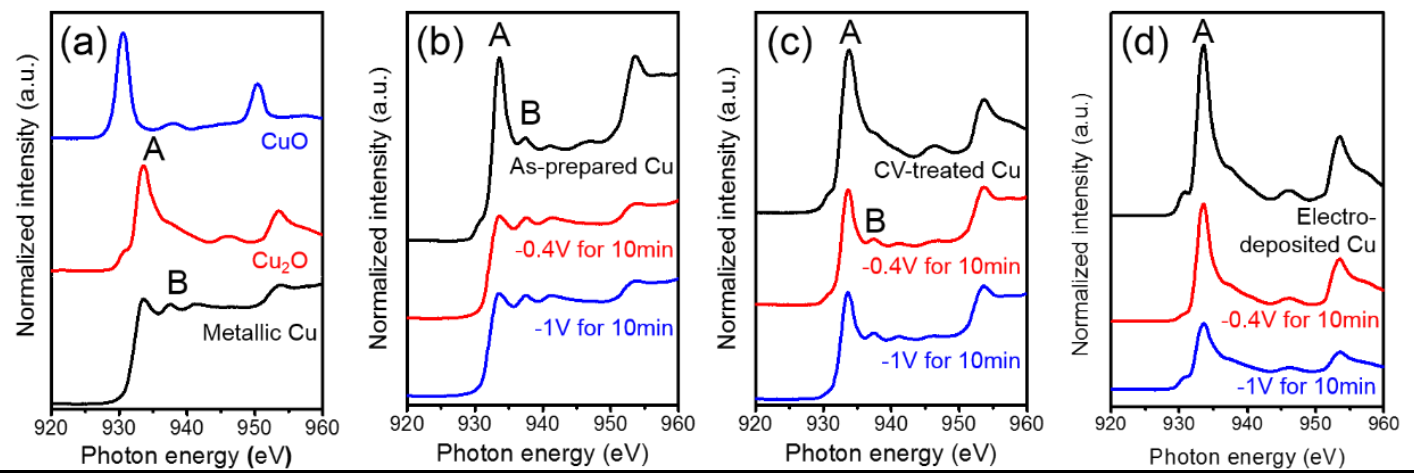

Figure 2. (a) $\mathrm{Cu} \mathrm{L}_{3}$-edge X-ray absorption spectra (XAS)-TEY mode of standard $\mathrm{Cu}$ electrodes. Ex situ $\mathrm{Cu}_{3}$-edge XAS of (b) as-prepared $\mathrm{Cu}$ electrode, (c) CV-treated $\mathrm{Cu}$ electrode (after three CV-treated cycles), and (d) electrodeposited $\mathrm{Cu}$ electrode obtained before and after $\mathrm{CO}_{2}$ reduction. The XAS were collected in TEY mode.

To study the oxidation state of different $\mathrm{Cu}$ surfaces, ex situ $\mathrm{Cu} \mathrm{L}_{3}$-edge soft $\mathrm{X}$ ray absorption spectroscopy were used to reveal the changes in oxidation state of $\mathrm{Cu}$ 
electrode prepared at representative potentials with $\mathrm{CO}_{2}$-saturated $0.1 \mathrm{M} \mathrm{KHCO}_{3}$ electrolyte. As compared to $\mathrm{Cu}$ K-edge hard X-ray absorption spectroscopy, the soft Xray absorption spectroscopy measurements collected in TEY mode can be used to study the oxidation state of $\mathrm{Cu}$ surface in a range of 2-20 nm thickness which provides surface information. ${ }^{38-39}$ Figure $2 \mathrm{a}$ shows $\mathrm{Cu}_{\mathrm{L}}$-edge X-ray absorption spectra (XAS)-TEY mode of $\mathrm{Cu}, \mathrm{Cu}_{2} \mathrm{O}$ and $\mathrm{CuO}$ electrodes as the reference spectra. ${ }^{37,40}$ Peak $\mathrm{A}$ at $933.6 \mathrm{eV}$ is associated with the feature of $\mathrm{Cu}(\mathrm{I})$ and peak $\mathrm{B}$ at $937.5 \mathrm{eV}$ is assigned to the metallic $\mathrm{Cu}(\mathrm{Cu}(0))$ in $\mathrm{Cu}$ electrode. ${ }^{37,40}$ Figure 2 b-d shows $\mathrm{Cu}_{3}$-edge XAS of (b) as-prepared $\mathrm{Cu}$ electrode, (c) $\mathrm{CV}$-treated $\mathrm{Cu}$ electrode (after three $\mathrm{CV}$-treated cycles), and (d) electrodeposited $\mathrm{Cu}$ electrode in TEY mode. The feature of peak A and B suggests that both $\mathrm{Cu}(0)$ and $\mathrm{Cu}(\mathrm{I})$ exist on the surface of as-prepared $\mathrm{Cu}$ electrode before $\mathrm{CO}_{2}$ reduction. (Fig. 2b) Thus, the XAS of as-prepared $\mathrm{Cu}$ electrode also exhibit $\mathrm{Cu}(\mathrm{I})$ feature before $\mathrm{CO} 2 \mathrm{RR}$. The existence of $\mathrm{Cu}(\mathrm{I})$ resulted from the surface oxidation of metallic copper under air conditions prior to immersion in the electrolyte has been proposed previously. ${ }^{41-42}$ The XAS of the electrodeposited $\mathrm{Cu}$ electrode and CV-treated $\mathrm{Cu}$ electrode indicate that $\mathrm{Cu}(\mathrm{I})$ dominates the $\mathrm{Cu}$ surface before $\mathrm{CO} 2 \mathrm{RR}$ and the $\mathrm{Cu}(0)$ feature could be embedded in the spectra. (Fig. 2c-d)

The prepared $\mathrm{Cu}$ electrodes are then held at representative potentials for $10 \mathrm{~min}$ during $\mathrm{CO}_{2}$ reduction. Figure $2 \mathrm{~b}$-d show that ex situ $\mathrm{Cu}_{3}$-edge XAS of (b) as-prepared 
$\mathrm{Cu}$ electrode, (c) $\mathrm{CV}$-treated $\mathrm{Cu}$ electrode, and (d) electrodeposited $\mathrm{Cu}$ electrode collected in TEY mode were obtained at representative potentials with $\mathrm{CO}_{2}$-saturated $0.1 \mathrm{M} \mathrm{KHCO}_{3}$ electrolyte. The oxidation state of as-prepared $\mathrm{Cu}$ electrode changes from the mixture of $\mathrm{Cu}(0)$ and $\mathrm{Cu}(\mathrm{I})$ to $\mathrm{Cu}(0)$ at $-0.4 \mathrm{~V}$ while the XAS of other two $\mathrm{Cu}$ catalysts are mainly showing the feature of $\mathrm{Cu}(\mathrm{I})$. The diminished $\mathrm{Cu}(\mathrm{I})$ at lower overpotential could be related to the small amount of $\mathrm{Cu}(\mathrm{I})$ in as-prepared $\mathrm{Cu}$ electrode. After further reduction at $-1 \mathrm{~V}$, the XAS of $\mathrm{CV}$-treated $\mathrm{Cu}$ exhibit that the intensity of peak A decreases and the feature of peak B becomes clear after holding the potential at $-1 \mathrm{~V}$ for $10 \mathrm{~min}$, suggesting that some $\mathrm{Cu}(\mathrm{I})$ are reduced to $\mathrm{Cu}(0)$ and both $\mathrm{Cu}(\mathrm{I})$ and $\mathrm{Cu}(0)$ still exist on the $\mathrm{Cu}$ surface. In contrast, although the electrodeposited $\mathrm{Cu}$ should also contain the $\mathrm{Cu}(0)$ oxidation state during the reaction, XAS of electrodeposited $\mathrm{Cu}$ mainly exhibit the $\mathrm{Cu}(\mathrm{I})$ feature after holding the potential at $-1 \mathrm{~V}$ for $10 \mathrm{~min}$. The reduction from $\mathrm{Cu}(\mathrm{I})$ to $\mathrm{Cu}(0)$ in electrodeposited $\mathrm{Cu}$ electrode takes longer time than that of the other $\mathrm{Cu}$ electrodes which could be attributed to the larger amount of $\mathrm{Cu}(\mathrm{I})$ on electrodeposited $\mathrm{Cu}$ surface.

The hard X-ray absorption spectroscopy (Cu K-edge) was used to characterize the changes in oxidation state of $\mathrm{Cu}$ materials. ${ }^{18}$ Figure $\mathrm{S} 7$ shows the $\mathrm{Cu}$ K-edge XAS of electrodeposited $\mathrm{Cu}$ electrode, as-prepared electrode and $\mathrm{CV}$-treated $\mathrm{Cu}$ electrode. Although $\mathrm{Cu} \mathrm{K}$-edge XAS involve the information about the oxidation state of bulk $\mathrm{Cu}$ 
metal $(>2 \mu \mathrm{m}),{ }^{43}$ extended X-Ray absorption fine structure (EXAFS) obtained on the as-prepared $\mathrm{Cu}$ electrode shows the peak at $2.2 \AA$ which is assigned to the $\mathrm{Cu}-\mathrm{Cu}$ bond. ${ }^{44-45}$ EXAFS of electrodeposited $\mathrm{Cu}$ electrode and $\mathrm{CV}$-treated $\mathrm{Cu}$ electrode shows the peak at $1.5 \AA$ associated with $\mathrm{Cu}-\mathrm{O}$ bond, suggesting that $\mathrm{Cu}(\mathrm{I})$ could result from the persistence of $\mathrm{Cu}$ oxides. ${ }^{18}$
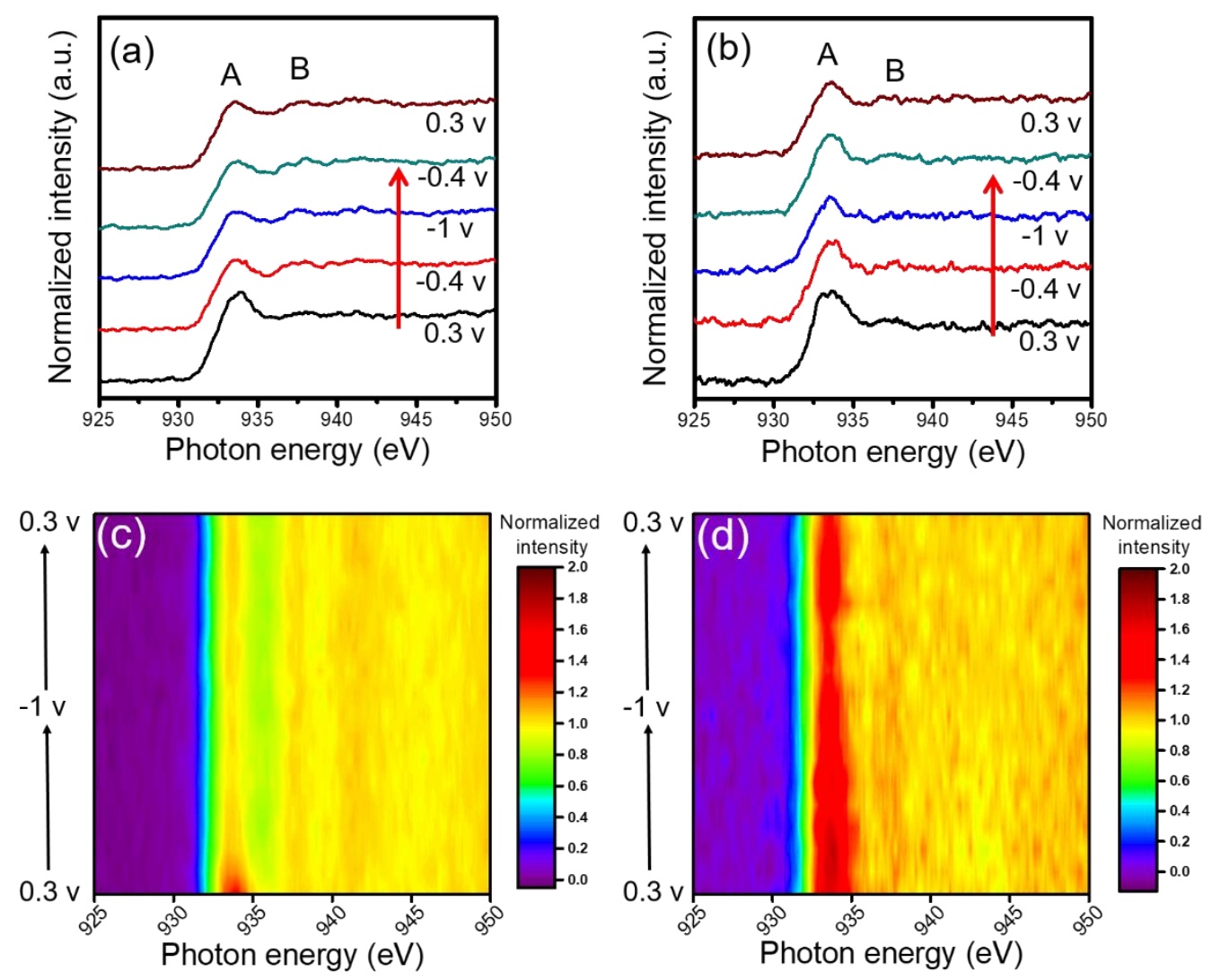

Figure 3. In situ $\mathrm{Cu} \mathrm{L}_{3}$-edge $\mathrm{XAS}$ of (a) as-prepared $\mathrm{Cu}$ electrode, (b) $\mathrm{CV}$-oxidized $\mathrm{Cu}$ electrode shown at representative potentials with $\mathrm{CO}_{2}$-saturated $0.1 \mathrm{M} \mathrm{KHCO}_{3}$. Contour plots of in situ $\mathrm{Cu} \mathrm{L}_{3}$-edge XAS of (c) as-prepared $\mathrm{Cu}$ and (d) $\mathrm{CV}$-treated $\mathrm{Cu}$ cycled between 0.3 and -1 V. In situ $\mathrm{Cu}_{3}$-edge XAS were collected in TFY mode.

To further examine the effect of $\mathrm{CV}$ treatment on the characteristics of $\mathrm{Cu}$ electrode during electrochemical $\mathrm{CO}_{2}$ reduction, we next performed in situ soft X-ray 
absorption spectroscopy measurements of as-prepared $\mathrm{Cu}$ electrode and $\mathrm{CV}$-treated $\mathrm{Cu}$ electrode to reveal the changes in oxidation state of $\mathrm{Cu}$ surface during electrochemical $\mathrm{CO}_{2}$ reduction. Although the information provided by XAS-TEY mode is more surface sensitive, electrochemical soft X-ray absorption measurements can be operated in TFY mode ${ }^{46}$ We show the XAS-TFY mode of standard Cu electrodes in Figure S8. In situ $\mathrm{Cu}_{3}$-edge XAS of as-prepared $\mathrm{Cu}$ electrode shown at representative potentials were obtained in the potential region of 0.3 and $-1 \mathrm{~V}$ (Figure 3a). The scan rate is $2 \mathrm{mV} \mathrm{s}^{-1}$ during cycling and the electrolyte is $\mathrm{CO}_{2}$-saturated $0.1 \mathrm{M} \mathrm{KHCO}_{3}$. Peak A at $933.6 \mathrm{eV}$ associated with the feature of $\mathrm{Cu}(\mathrm{I})$ appears at $0.3 \mathrm{~V} \cdot{ }^{41}$ During the $\mathrm{CO}_{2}$ reduction process, the intensity of Peak A decreases during the scan from 0.3 to $-1 \mathrm{~V}$, indicating that the oxidation state of $\mathrm{Cu}$ surface changes from $\mathrm{Cu}(\mathrm{I})$ to metallic $\mathrm{Cu}$. The oxidation state of as-prepared $\mathrm{Cu}$ electrode persists $\mathrm{Cu}(0)$ during the backward scan from -1 to $0.3 \mathrm{~V}$. In contrast, in situ $\mathrm{Cu}_{3}$-edge XAS of CV-treated $\mathrm{Cu}$ (after three $\mathrm{CV}$-treated cycles) still exhibit the combination of $\mathrm{Cu}(\mathrm{I})$ and $\mathrm{Cu}(0)$ feature during cycling (Figure $3 \mathrm{~b}$ ).

Figure 3c-d shows the contour plots of in situ $\mathrm{Cu} \mathrm{L}_{3}$-edge XAS of (c) as-prepared $\mathrm{Cu}$ and $(\mathrm{d}) \mathrm{CV}$-treated $\mathrm{Cu}$ cycled between 0.3 and $-1 \mathrm{~V}$ with $\mathrm{CO}_{2}$-saturated $0.1 \mathrm{M}$ $\mathrm{KHCO}_{3}$ electrolyte. In situ $\mathrm{Cu} \mathrm{L}_{3}$-edge XAS of as-prepared $\mathrm{Cu}$ show that the intensity of $\mathrm{Cu}(\mathrm{I})$ decreases rapidly during $\mathrm{CO}_{2}$ reduction process (Figure $3 \mathrm{c}$ ). In contrast, Figure $3 \mathrm{~d}$ shows that the feature of $\mathrm{Cu}(\mathrm{I})$ obtained at $0.3 \mathrm{~V}$ becomes weaker during cycling. 
We found that the reduction of $\mathrm{Cu}(\mathrm{I})$ to $\mathrm{Cu}(0)$ in $\mathrm{CV}$-treated $\mathrm{Cu}$ is much slower, suggesting that the reduction of oxidation state over these $\mathrm{Cu}$ electrodes is a timedependent process during $\mathrm{CO}_{2}$ reduction.
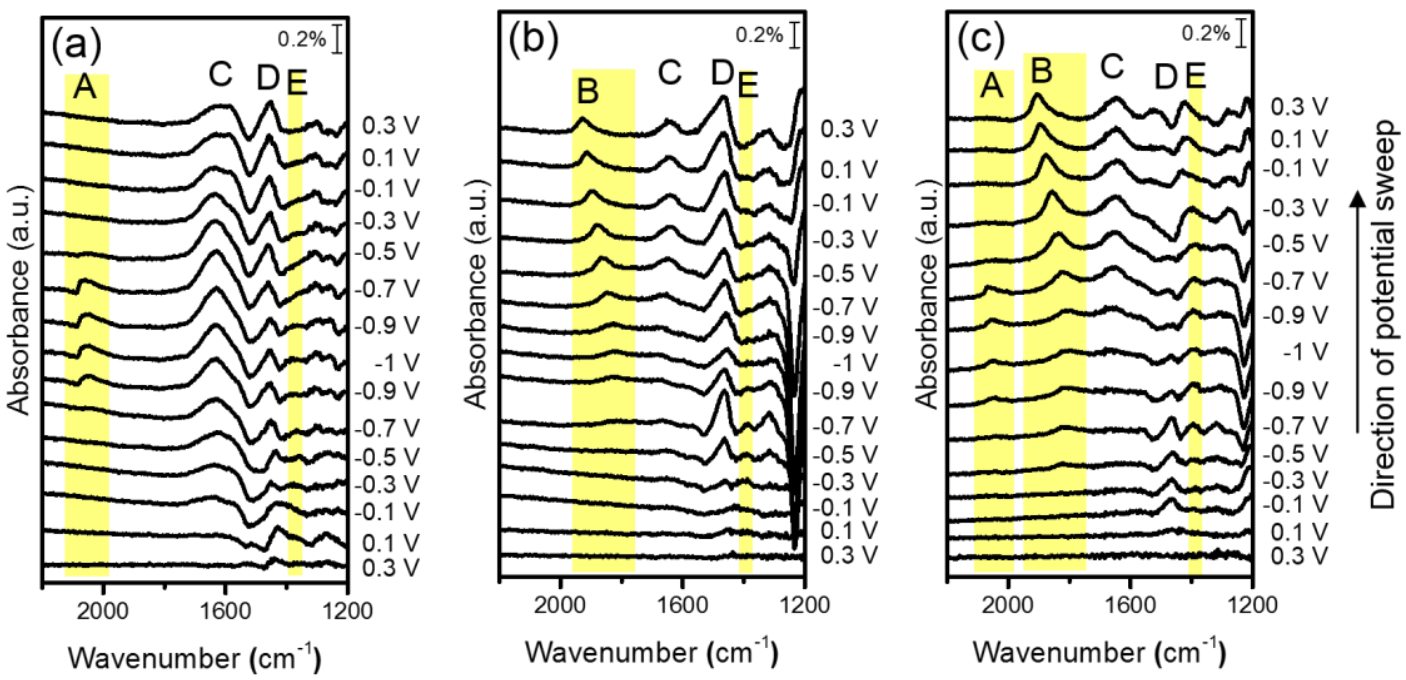

Figure 4. In situ SEIRAS of (a) electrodeposited $\mathrm{Cu}$ electrode, (b) as-prepared $\mathrm{Cu}$ electrode and (c) $\mathrm{CV}$-treated $\mathrm{Cu}$ electrode (after three $\mathrm{CV}$-treated cycles) during cathodic (negative) scan and anodic (positive) scan in $\mathrm{CO}_{2}$-saturated $0.1 \mathrm{M}$ $\mathrm{KHCO}_{3}$ electrolyte.

In order to understand the effect of valance state of $\mathrm{Cu}$ surface on the $\mathrm{CO}_{2}$ reduction mechanism, we used in situ surface-enhanced infrared absorption spectroscopy (SEIRAS) to identify the intermediates formed on different $\mathrm{Cu}$ surface during $\mathrm{CO}_{2}$ reduction. IR spectra were collected every $100 \mathrm{mV}$ during a potential step. All the IR spectra are shown in Figure S9. Figure 4 shows in situ SEIRA spectra of (a) electrodeposited $\mathrm{Cu}$ electrode, (b) as-prepared $\mathrm{Cu}$ electrode and (c) $\mathrm{CV}$-treated $\mathrm{Cu}$ electrode obtained at representative potentials during the first cycle. Reference spectra were obtained at $0.3 \mathrm{~V}$ in $\mathrm{CO}_{2}$-saturated $0.1 \mathrm{M} \mathrm{KHCO}_{3}$ electrolyte. Figure 4a shows the 
in situ SEIRA spectra of electrodeposited $\mathrm{Cu}$ electrode collected in the cathodic (negative) scan from 0.3 to $-1 \mathrm{~V}$. Peak A at $2048 \mathrm{~cm}^{-1}$ corresponding to atop-adsorbed $\mathrm{CO}\left(\mathrm{CO}_{\text {atop }}\right)$ on $\mathrm{Cu}$ surface appears during the negative scan. The asymmetric peak $\mathrm{A}$ is observed as the potential is shifted to $-1 \mathrm{~V}^{47} \mathrm{CO}_{\text {atop }}$ disappears during the anodic (positive) scan. Among various adsorbed $\mathrm{CO}$ species, $\mathrm{CO}_{\text {atop }}$ is formed alone on the electrodeposited $\mathrm{Cu}$ surface during $\mathrm{CO}_{2}$ reduction. ${ }^{24,}{ }^{26}$ The position of $\mathrm{CO}_{\text {atop- }}$ associated peak obtained on $\mathrm{Cu}$ surface $\left(2080-2040 \mathrm{~cm}^{-1}\right)$ is different from the position

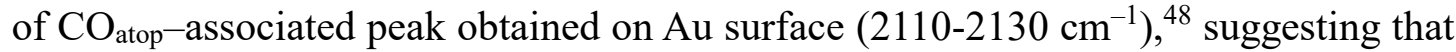
the electrodeposited $\mathrm{Cu}$ electrode completely covers the underlying Au surface.

In contrast, Figure $4 \mathrm{~b}$ shows the in situ SEIRA spectra of as-prepared $\mathrm{Cu}$ electrode, clearly revealing peak B at $1832 \mathrm{~cm}^{-1}$ during negative scan. Peak B associated with bridge-adsorbed $\mathrm{CO}\left(\mathrm{CO}_{\text {bridge}}\right)$ on $\mathrm{Cu}$ surface is obtained at $-0.5 \mathrm{~V}$ and gradually redshifts to $1827 \mathrm{~cm}^{-1}$ at $-1 \mathrm{~V}$ during the negative scan. Upon scanning the potential from -1 to $0.3 \mathrm{~V}$, peak B then blueshifts from 1827 to $1930 \mathrm{~cm}^{-1}$. Similar potentialdependent behavior of surface-adsorbed $\mathrm{CO}_{\text {bridge }}$ has been reported on $\mathrm{Cu}^{27}$ The blueshift in vibrational frequency of $\mathrm{CO}_{\text {bridge }}$ is ascribed to the decrease in the dipoledipole interaction among $\mathrm{CO}_{\text {bridge }}$ molecules and/or electron back-donation from the $\mathrm{Cu}$ surface to the $\mathrm{CO}_{\text {bridge }}$ molecules. ${ }^{27,}{ }^{49}$ Peak $\mathrm{C}$ is associated with the $\mathrm{H}-\mathrm{O}-\mathrm{H}$ bending mode of adsorbed water on the $\mathrm{Cu}$ surface and peak $\mathrm{D}$ is assigned to $\mathrm{HCO}_{2}{ }^{-35}{ }^{50-51}$ The 
irreversible changes in the adsorption behavior of adsorbed water during cycling is consistent with previous studies. ${ }^{35}$ The role of adsorbed water in $\mathrm{CO}_{2}$ reduction mechanism is discussed in supporting information.

Interestingly, in situ SEIRA spectra of CV-treated Cu electrode show the formation of both $\mathrm{CO}_{\text {atop }}$ and $\mathrm{CO}_{\text {bridge }}$ during $\mathrm{CO}_{2}$ reduction, suggesting that $\mathrm{CO}_{2}$ reduction mechanism over the as-prepared $\mathrm{Cu}$ surface is changed after the $\mathrm{CV}$ treatment (Figure 2c). Although porous $\mathrm{Cu}$ materials effectively enhance vibrational signatures of surface adsorbates, which allows us to probe surface species, ${ }^{52}$ the AFM images of as-prepared $\mathrm{Cu}$ surface and $\mathrm{CV}$-treated $\mathrm{Cu}$ surface (after three $\mathrm{CV}$-treated cycles) show a similar roughness of the $\mathrm{Cu}$ surfaces and the $\mathrm{IR}$ intensities of $\mathrm{CO}_{\text {bridge-associated peaks }}$ obtained over the two $\mathrm{Cu}$ electrodes are the same. Thus, the appearance of $\mathrm{CO}_{\text {atop }}$ in $\mathrm{CV}$-treated $\mathrm{Cu}$ surface resulted from different plasmonic absorption properties of $\mathrm{Cu}$ surface can be excluded. In addition, peak E associated with $\mathrm{COO}^{-}$is formed, followed by the formation of $\mathrm{CO}_{\text {atop }}$ and $\mathrm{CO}_{\text {bridge. }}$ The intensity of peak $\mathrm{E}$ decreases in further reduction. Peak assignments are summarized in Table 1. 24-29, 50-51, 53-54

Figure S10 shows the in situ SEIRA spectrum of CV-treated Cu electrode obtained at $-1 \mathrm{~V}$, exhibiting that both $\mathrm{CO}_{\text {bridge }}$ and $\mathrm{CO}_{\text {atop }}$ adsorbed on the $\mathrm{Cu}$ surface. We then remove the potential control and replace the electrolyte with fresh $\mathrm{CO}_{2}$-saturated $0.1 \mathrm{M}$ $\mathrm{KHCO}_{3}$ electrolyte without exposing the $\mathrm{Cu}$ electrode to air. On the measured anew 
SEIRA spectrum of $\mathrm{CV}$-treated $\mathrm{Cu}$ electrode, the $\mathrm{CO}_{\text {atop-associated peak disappears. }}$

The fact that $\mathrm{CO}_{\text {atop }}$ can be removed from the surface without the applied potential suggests that the formation of $\mathrm{CO}_{\text {atop }}$ on the $\mathrm{Cu}$ surface is a dynamic adsorption process.

\begin{tabular}{cccc}
\hline Peak label & Peak position $\left(\mathrm{cm}^{-1}\right)$ & Assignments & Literature reference \\
\hline A & $1951 \sim 2094$ & CO stretching in atop adsorbed CO & $24-29$ \\
B & $1806 \sim 1907$ & CO stretching in bridge adsorbed CO & $27-29$ \\
C & 1645 & H-O-H bending of $\mathrm{H}_{2} \mathrm{O}$ & 25,26 \\
D & 1467 & C-O stretching of $\mathrm{HCO}_{2}^{-}$ & 50,51 \\
E & 1396 & $\mathrm{COO}^{-}$symmetric stretching & $24,53,54$ \\
\hline
\end{tabular}

Table 1. Experimental vibrational frequencies and assignments for the species in electrochemical $\mathrm{CO}_{2}$ reduction.
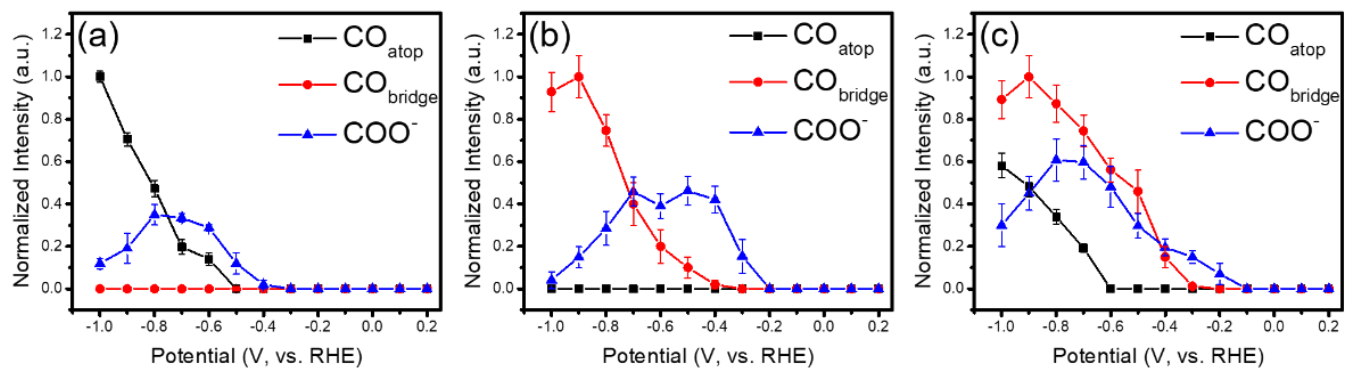

Figure 5. Potential dependence of the intensity of $\mathrm{CO}_{\text {atop }}, \mathrm{CO}_{\text {bridge }}$ and $\mathrm{COO}^{-}$obtained in (a) electrodeposited $\mathrm{Cu}$ electrode, (b) as-prepared $\mathrm{Cu}$ electrode and (c) $\mathrm{CV}$-treated $\mathrm{Cu}$ electrode from 0.2 to $-1 \mathrm{~V}$ taken from Figure 4.

Figure 5 shows the potential dependence of the intensity of $\mathrm{CO}_{\text {bridge }}, \mathrm{CO}_{\text {atop }}$ and $\mathrm{COO}^{-}$obtained in (a) electrodeposited $\mathrm{Cu}$ electrode, (b) as-prepared $\mathrm{Cu}$ electrode and (c) $\mathrm{CV}$-treated $\mathrm{Cu}$ electrode from 0.2 to $-1 \mathrm{~V}$ taken from Figure 4. All peak intensities were normalized to the most intense peak at specific potential. The $\mathrm{CO}_{\text {atop-associated }}$ peak is observed at $-0.6 \mathrm{~V}$ and drastically increases from -0.6 to $-1 \mathrm{~V}$ in electrodeposited $\mathrm{Cu}$ electrode (Figure 5a). The peak associated with $\mathrm{COO}^{-}$appears at $-0.4 \mathrm{~V}$ and gradually increases in further reduction. Figure $5 \mathrm{~b}$ shows that $\mathrm{CO}_{\text {bridge-associated peak }}$ appears at $-0.4 \mathrm{~V}$ in the as-prepared $\mathrm{Cu}$ electrode, while $\mathrm{CO}_{\text {atop-associated peak is absent }}$ 
during the $\mathrm{CO}_{2}$ reduction. Notably, both $\mathrm{CO}_{\text {bridge }}$ and $\mathrm{CO}_{\text {atop-associated peaks are }}$ obtained in the $\mathrm{CV}$-treated $\mathrm{Cu}$ electrode which could be related to the formation of different final products (Figure 5c).
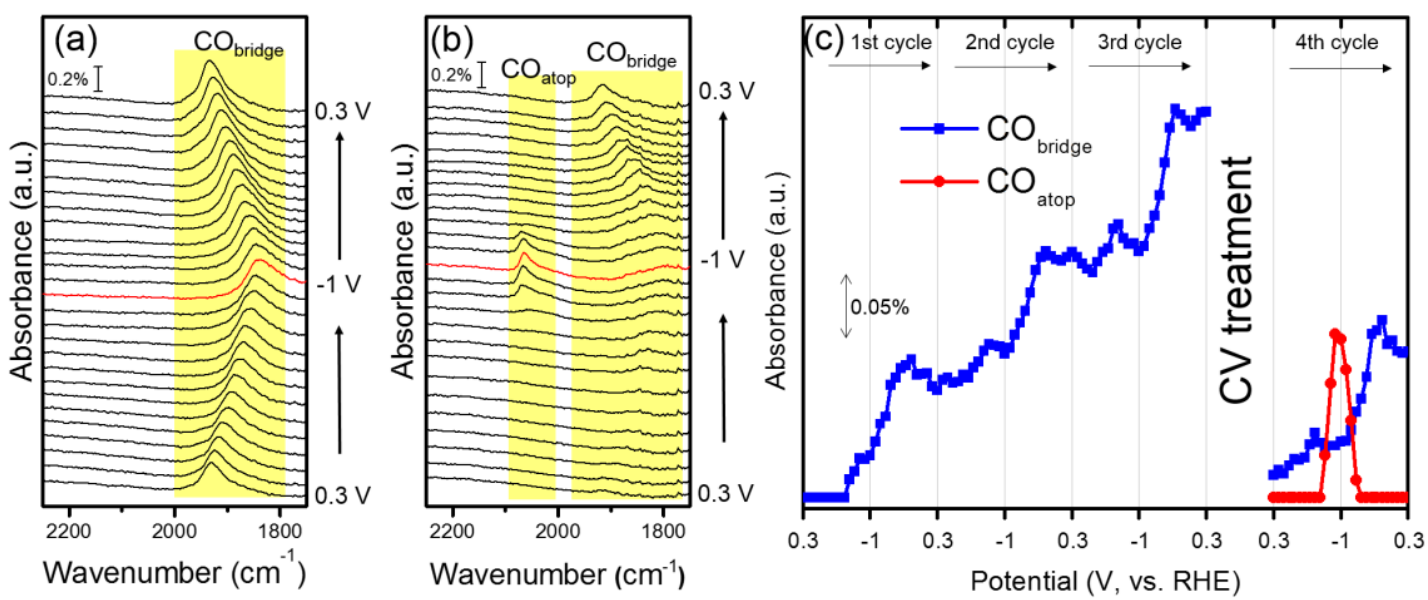

Figure 6. In situ SEIRA spectra of (a) as-prepared Cu electrode obtained in the (a) 3rd cycle and the (b) 4th cycle of $\mathrm{CO}_{2}$ reduction process (after CV-treated cycles). (c) Potential-dependence of intensity of $\mathrm{CO}_{\text {bridge }}$ and $\mathrm{CO}_{\text {atop-associated peaks during four }}$ cycles.

We next study the formation of $\mathrm{CO}_{\text {bridge }}$ and $\mathrm{CO}_{\text {atop }}$ species during continuous cycles. Figure $6 \mathrm{a}-\mathrm{b}$ shows the in situ SEIRAS of as-prepared $\mathrm{Cu}$ electrode obtained in the 3 rd cycle and the 4 th cycle of $\mathrm{CO}_{2}$ reduction process (after $\mathrm{CV}$-treated cycles). The reference spectrum is obtained at $0.3 \mathrm{~V}$ before the $\mathrm{CO}_{2}$ reduction. The $\mathrm{CO}_{\text {bridge- }}$ associated peak resulted from the residual $\mathrm{CO}_{\text {bridge }}$ on the $\mathrm{Cu}$ surface is observed at 0.3

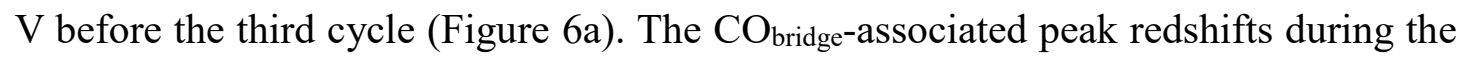
negative scan and blueshifts during the backward scan between $0.3 \mathrm{~V}$ and $-1 \mathrm{~V}$, indicating that the adsorption behavior of residual $\mathrm{CO}_{\text {bridge }}$ is the same during continuous cycles. 
Figure 6c shows the potential-dependence of intensity of $\mathrm{CO}_{\text {bridge }}$ and $\mathrm{CO}_{\text {atop- }}$ associated peaks during continuous four cycles. We found that the growth of residual $\mathrm{CO}_{\text {bridge }}$ is facilitated by polarizing the potential below $-0.5 \mathrm{~V}$ during $\mathrm{CO}_{2}$ reduction.

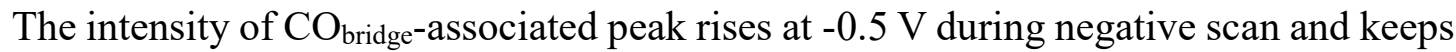
increasing during backward scan until $-0.3 \mathrm{~V}$, suggesting that residual $\mathrm{CO}_{\text {bridge }}$ species is formed on the surface. The total amount of residual $\mathrm{CO}_{\text {bridge }}$ increases from the first

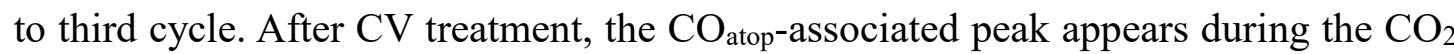
reduction, which could be related to the formation of $\mathrm{Cu}(\mathrm{I})$. The intensity of $\mathrm{CO}_{\text {bridge- }}$ associated peak drops, suggesting that $\mathrm{CO}_{\text {bridge }}$ can be removed from $\mathrm{Cu}$ surface during $\mathrm{Cu}$ oxidation process. ${ }^{27}$

Possible reasons for the growth of residual $\mathrm{CO}_{\text {bridge }}$ during cycles are proposed as followings. (1) The increase in surface roughness of $\mathrm{Cu}$ electrode could provide more surface area for $\mathrm{CO}_{\text {bridge }}$ adsorption during cycling. Although AFM images show that the surface roughness of as-prepared $\mathrm{Cu}$ electrodes is similar before and after three $\mathrm{CV}$ treated cycles in the potential range of -0.3 and $0.55 \mathrm{~V}$ (Fig. 1b-c), the surface reconstruction of as-prepared $\mathrm{Cu}$ electrode could only take place at the atomic level. In addition, AFM image of the surface morphology of CV-treated $\mathrm{Cu}$ electrode (after 100 CV-treated cycles) shows that the surface becomes rougher. (Fig. S11) (2) In situ SEIRA spectra of $\mathrm{Cu}$ electrodes show that the peaks associated with $\delta_{\mathrm{HOH}}$ bending mode of 
adsorbed water appear during the negative scan and maintain during the backward scan, ${ }^{35}$ which is most likely due to the irreversible changes of the $\mathrm{Cu}$ surface. (3) The increase in the amount of residual $\mathrm{CO}_{\text {bridge }}$ is similar during each cycle, suggesting that $\mathrm{CO}_{\text {bridge }}$ species occupy a portion of $\mathrm{Cu}$ surface. Polycrystalline $\mathrm{Cu}$ electrode reconstructs and forms $\mathrm{Cu}(111)$ and $\mathrm{Cu}(100)$ facets in the electrolyte ${ }^{55-56}$ and COinduced surface reconstruction has been reported. ${ }^{47}$ Thus, the irreversible surface reconstruction could lead to form more favorable sites for $\mathrm{CO}_{\text {bridge }}$ adsorption during cycling.
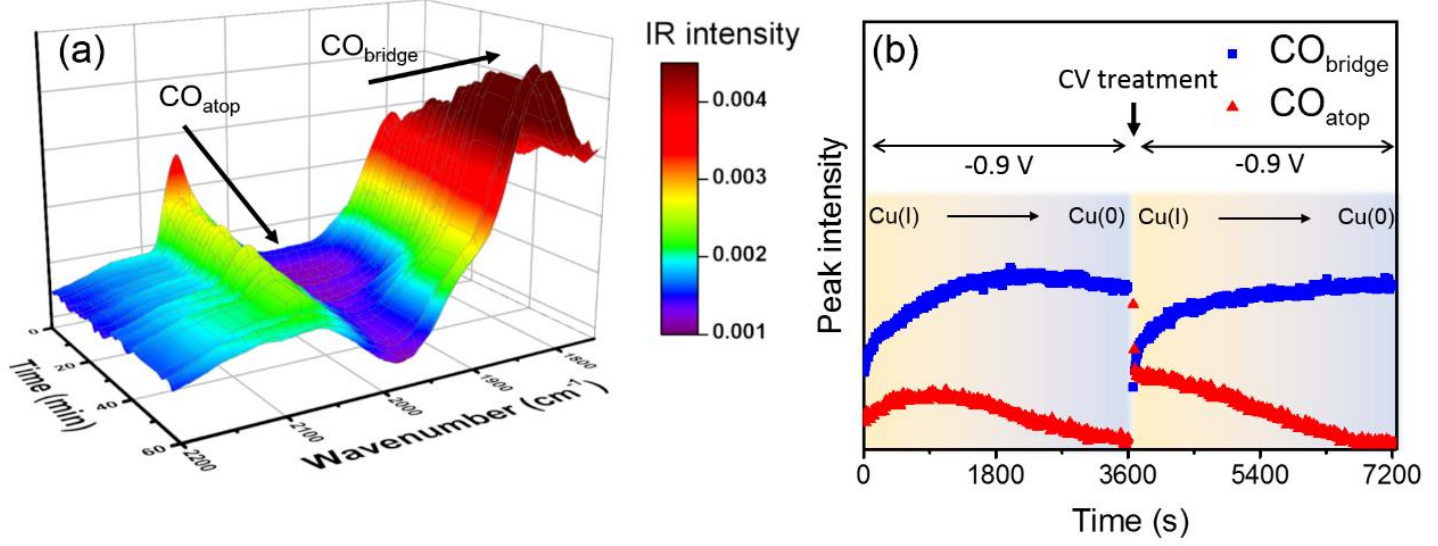

Figure 7. (a) In situ SEIRA spectra of CV-treated Cu electrode and (b) time dependence

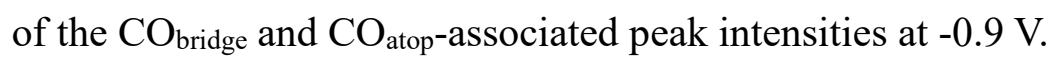

In order to study the persistence of the different $\mathrm{CO}$ species during $\mathrm{CO}_{2}$ reduction, we examined the SEIRA spectra of $\mathrm{CV}$-treated $\mathrm{Cu}$ electrode obtained with time, during a holding-potential at -0.9 V. Figure 7 a shows the in situ SEIRA spectra of CV-treated $\mathrm{Cu}$ electrode and that obtained after holding the potential at $-0.9 \mathrm{~V}$ for $60 \mathrm{~min}$. The

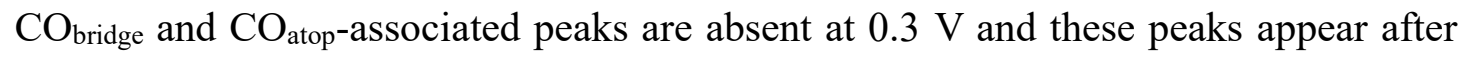


stepping the potential from 0.3 to $-0.9 \mathrm{~V}$. Figure $7 \mathrm{~b}$ shows the time dependence of the

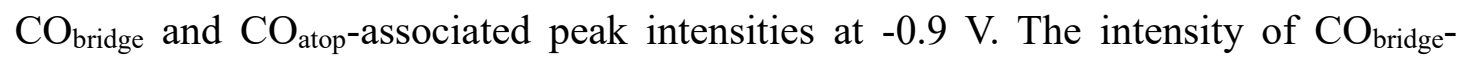
associated peak reaches maximum in $\sim 30$ min and remains at $-0.9 \mathrm{~V}$. In contrast, the

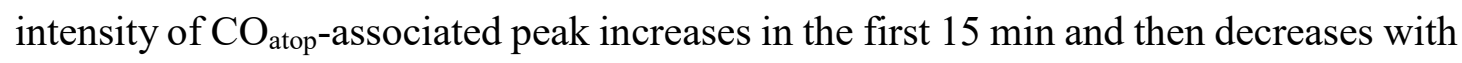
the time. The decrease in the intensity of $\mathrm{CO}_{\text {atop }}$ suggests that $\mathrm{CO}_{\text {atop }}$ leaves the surface easily and $\mathrm{CO}_{\text {atop }}$ adsorption is a dynamic process. The XAS of $\mathrm{CV}$-treated $\mathrm{Cu}$ electrode obtained during a potential hold at $-0.9 \mathrm{~V}$ mainly exhibit $\mathrm{Cu}(\mathrm{I})$ feature for the first 15 min which is due to the slow reduction of $\mathrm{Cu}(\mathrm{I})$. After holding the potential at $-0.9 \mathrm{~V}$ for $60 \mathrm{~min}$, the oxidation state of $\mathrm{Cu}$ surface changes from $\mathrm{Cu}(\mathrm{I})$ to $\mathrm{Cu}(0)$.

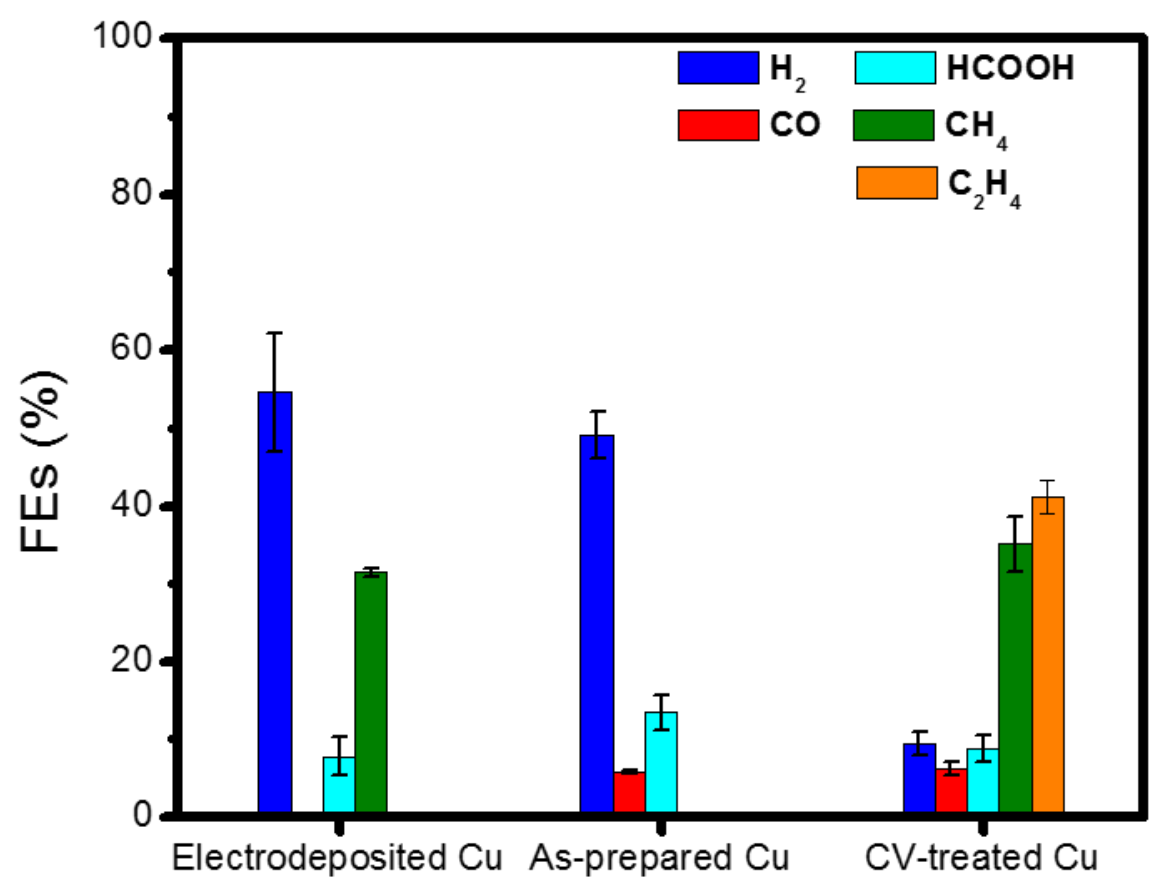

Figure 8. FEs of major products catalyzed by electrodeposited $\mathrm{Cu}$ electrode, asprepared $\mathrm{Cu}$ electrode and $\mathrm{CV}$-treated $\mathrm{Cu}$ electrode (after $100 \mathrm{CV}$-treated cycles) at -1 
$\mathrm{V}$ in $\mathrm{CO}_{2}$ saturated $0.1 \mathrm{M} \mathrm{KHCO}_{3}$ electrolyte.

The product distributions obtained from various $\mathrm{Cu}$ catalysts were used to examine the electrocatalytic properties of $\mathrm{Cu}$ and gain more insight into the $\mathrm{CO}_{2}$ reduction mechanism. Figure 8 shows the FEs of major products catalyzed by electrodeposited $\mathrm{Cu}$ electrode, as-prepared $\mathrm{Cu}$ electrode and $\mathrm{CV}$-treated $\mathrm{Cu}$ electrode (after $100 \mathrm{CV}$ treated cycles) at $-1 \mathrm{~V}$. The major products catalyzed by electrodeposited $\mathrm{Cu}$ electrode at $-1 \mathrm{~V}$ are $\mathrm{H}_{2}, \mathrm{CH}_{4}$ and $\mathrm{HCOOH}$ with the $\mathrm{FEs}$ of $50 \%, 30 \%$ and $10 \%$, respectively. In addition, only small amount of $\mathrm{C}_{2}$ product such as $\mathrm{C}_{2} \mathrm{H}_{4}$ can be produced at even higher overpotential, which is consistent with previous studies. ${ }^{25}$

The major $\mathrm{CO}_{2}$ reduction products over the as-prepared $\mathrm{Cu}$ electrode are $\mathrm{H}_{2}, \mathrm{CO}$ and $\mathrm{HCOOH}$ at $-1 \mathrm{~V}$, with the FEs being $50 \%, 5 \%$, and $10 \%$ at $-1 \mathrm{~V}$, respectively. $\mathrm{H}_{2}$ becomes the dominant product, indicating that the high FE toward hydrogen evolution reaction is observed in as-prepared $\mathrm{Cu}$ electrode and less hydrocarbon products can be formed. In order to provide a significant effect of $\mathrm{CV}$ treatment on the final product analysis, the $\mathrm{CV}$-treated $\mathrm{Cu}$ electrode is prepared after $100 \mathrm{CV}$-treated cycles for the on-line $\mathrm{GC}$ measurements. The $\mathrm{CV}$-treated $\mathrm{Cu}$ electrode (after $100 \mathrm{CV}$-treated cycles) produces more hydrocarbon species such as $\mathrm{C}_{2} \mathrm{H}_{4}(\mathrm{FE}=40 \%)$ and $\mathrm{CH}_{4}(\mathrm{FE}=35 \%)$, suggesting that the presence of $\mathrm{CO}_{\text {bridge }}$ and $\mathrm{CO}_{\text {atop }}$ leads to form different products. The improved selectivity can be observed even with less CV-treated cycles (Figure S12).

In addition, similar $\mathrm{FE}$ of $\mathrm{HCOOH}$ is obtained over the three $\mathrm{Cu}$ catalysts at $-1 \mathrm{~V}$, 
suggesting that the oxidation state of $\mathrm{Cu}$ and formation of $\mathrm{CO}$ species could have less effect on the formation of $\mathrm{HCOOH} .{ }^{13}$ The lower total FE $(\sim 65 \%)$ of major products obtained in the as-prepared $\mathrm{Cu}$ electrode could result from the formation of residual $\mathrm{CO}$ ( $\mathrm{CO}_{\text {bridge}}$ ) on as-prepared $\mathrm{Cu}$ surface at $-1 \mathrm{~V}$ shown in Figure 7. The $\mathrm{CV}$-treated $\mathrm{Cu}$ electrode with the coexistence of $\mathrm{Cu}(\mathrm{I})$ and $\mathrm{Cu}(0)$ results in the formation of $\mathrm{CH}_{4}$ and $\mathrm{C}_{2} \mathrm{H}_{4}$ at $-1 \mathrm{~V}$. Both $\mathrm{CH}_{4}(\mathrm{FE}=35 \%)$ and $\mathrm{C}_{2} \mathrm{H}_{4}(\mathrm{FE}=40 \%)$ are primary $\mathrm{CO}_{2}$ reduction products and the $\mathrm{FE}$ of $\mathrm{H}_{2}$ dramatically decreases to $\sim 10 \%$.

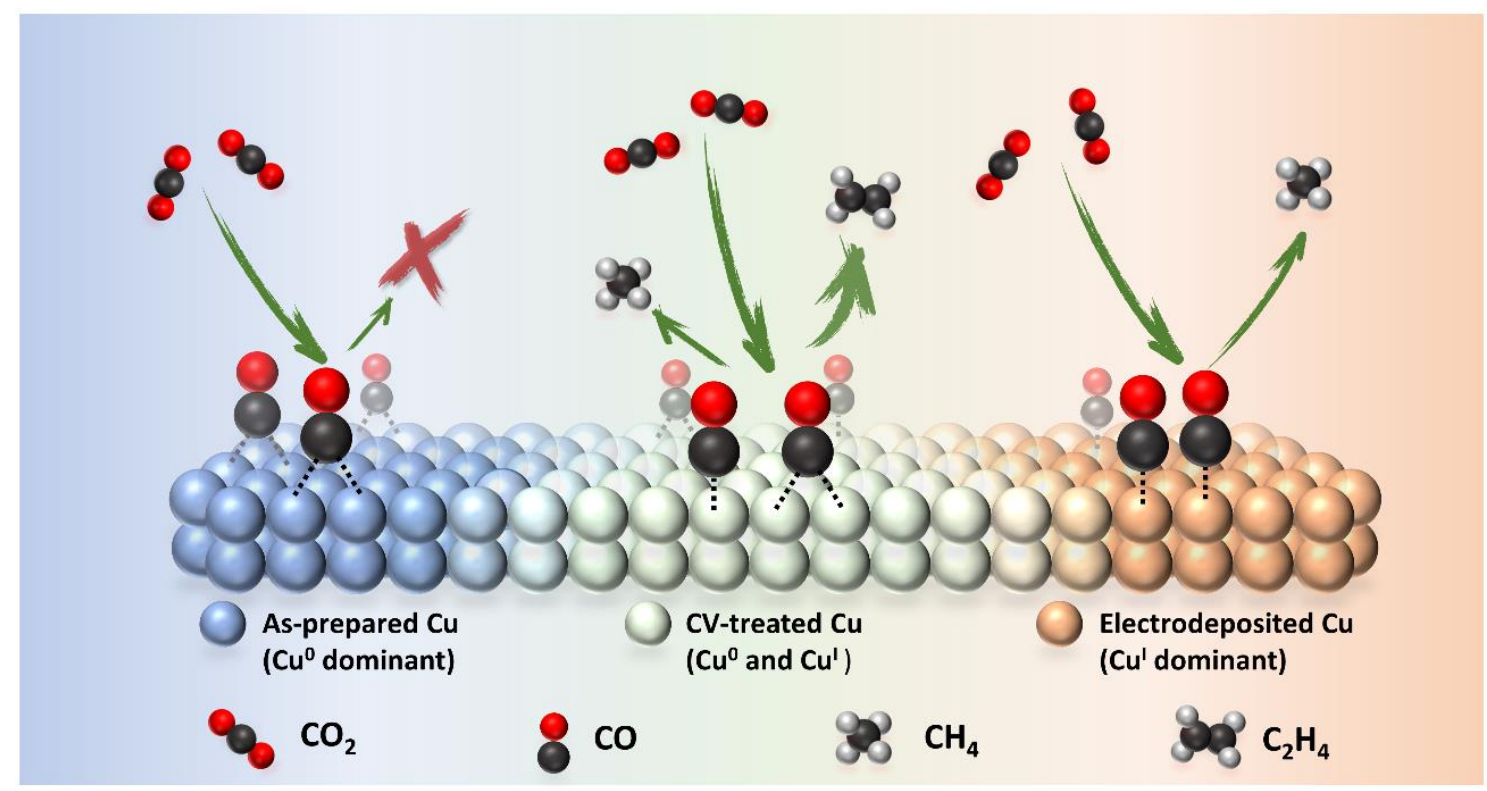

Scheme 1. Schematic illustration of electrochemical $\mathrm{CO}_{2}$ reduction on $\mathrm{Cu}$ surface.

We next discuss the possible reasons for the improved $\mathrm{CO}_{2}$ reduction catalyzed by $\mathrm{CV}$-treated $\mathrm{Cu}$ electrode. Previous studies showed that $\mathrm{C}_{2}$ products are favored on dendritic or branched copper materials. ${ }^{11,14}$ The branched copper oxide nanoparticles exhibited a high $\mathrm{FE}$ of ethylene $(\mathrm{FE}=70 \%)$ and a hydrogen $\mathrm{FE}$ of $30 \%$ without any byproducts in a neutral aqueous solution. ${ }^{11}$ Also, the surface morphology of $\mathrm{Cu}$ 
electrode has been proposed to change the $\mathrm{CO}_{2}$ reduction pathway. The surface reorganization of $\mathrm{Cu}$ (polycrystalline) surface to $\mathrm{Cu}($ polycrystalline)-[Cu(100)] surface is a general phenomenon at the negative potential ${ }^{55-56}$ and $\mathrm{Cu}(100)$ surface requires the lower overpotential to reduce $\mathrm{CO}_{2}$ to $\mathrm{C}_{2} \mathrm{H}_{4} \cdot{ }^{57-58}$ However, the $\mathrm{CV}$-treated $\mathrm{Cu}$ electrode exhibits similar surface morphology before and after $\mathrm{CO}_{2}$ reduction (Fig.1c, Fig. S11 and Fig. S13). Fig. S14 shows that the FEs of methane and ethylene products catalyzed by $\mathrm{CV}$-treated $\mathrm{Cu}$ electrode (after three $\mathrm{CV}$-treated cycles) decrease with the time after holding the potential at $-1 \mathrm{~V}$. The decreases in the product selectivity with time are not consistent with surface reorganization of $\mathrm{Cu}(100)$ for favorable $\mathrm{CO}_{2}$-to-ethylene conversion. Moreover, the product distributions obtained in the $\mathrm{CV}$-treated $\mathrm{Cu}$ catalysts and dendritic or branched copper materials are different. Thus, the product distributions are not fully correlated with the changes in surface morphology in the present study.

The role of $\mathrm{Cu}$ oxidation state has been examined in the product selectivity. We prepared $\mathrm{Cu}$ electrodes with the oxidation state of $\mathrm{Cu}(0)$ (i.e., as-prepared $\mathrm{Cu}$ electrode), $\mathrm{Cu}(\mathrm{I})$ (i.e., electrodeposited $\mathrm{Cu}$ electrode) and the mixture of $\mathrm{Cu}(0)$ and $\mathrm{Cu}(\mathrm{I})$ (i.e., $\mathrm{CV}$ treated $\mathrm{Cu}$ electrode) in the present study. The proposed electrochemical $\mathrm{CO}_{2}$ reduction mechanism on different $\mathrm{Cu}$ catalysts is shown in scheme 1. In situ SEIRA spectra show that different $\mathrm{CO}$ species are formed on these $\mathrm{Cu}$ surfaces. The electrodeposited $\mathrm{Cu}$ electrode shows that $\mathrm{Cu}(\mathrm{I})$ is the dominant. $\mathrm{CO}_{\text {atop }}$ intermediate species is obtained over 
electrodeposited $\mathrm{Cu}$ electrode, which could lead to form $\mathrm{CH}_{4}$ as the $\mathrm{C}_{1}$ product. The residual $\mathrm{CO}_{\text {bridge }}$ and less hydrocarbon product are obtained in the as-prepared $\mathrm{Cu}$ electrode with $\mathrm{Cu}(0)$. In the $\mathrm{CV}$-treated $\mathrm{Cu}$ electrode, XAS show the combination of $\mathrm{Cu}(\mathrm{I})$ and $\mathrm{Cu}(0)$ feature. The presence of both $\mathrm{CO}_{\text {atop }}$ and $\mathrm{CO}_{\text {bridge }}$ intermediate species on $\mathrm{Cu}$ surface is observed and the formation of $\mathrm{C}_{2}$ products such as $\mathrm{C}_{2} \mathrm{H}_{4}$ is enhanced. Although surface-adsorbed $\mathrm{CO}_{\text {bridge }}$ has been considered as the irreversible $\mathrm{CO}$ species, which is inert to the reduction reaction, ${ }^{27}$ our results suggest that $\mathrm{CO}_{\text {bridge }}$ might play an important role in producing the $\mathrm{C}_{2}$ products in the presence of $\mathrm{CO}_{\text {atop. }}$ Quantum mechanics method was used to validate a unique catalyst for electrochemical $\mathrm{CO}_{2}$ reduction. ${ }^{23}$ Xiao et al. proposed that the selectivity and activity of $\mathrm{C}_{2}$ products are enhanced at the borders of oxidized and metallic surface regions. ${ }^{23}$ Based on their proposed model, two $\mathrm{CO}$ species including $\mathrm{CO}_{\text {bridge }}$ and $\mathrm{CO}_{\text {atop }}$ adsorbed on $\mathrm{Cu}(0)$ and $\mathrm{Cu}(\mathrm{I})$ regions are negatively and positively charged, respectively, which assist the $\mathrm{CO}$ dimerization and form valuable chemicals products $\left(\mathrm{HCO}_{\mathrm{x}}\right)$. Thus, the theoretical model might correlate with the coexistence of $\mathrm{CO}_{\text {bridge }}$ and $\mathrm{CO}_{\text {atop }}$ intermediates for the improved formation of $\mathrm{C}_{2}$ product in the $\mathrm{CV}$-treated $\mathrm{Cu}$ electrode.

\section{Conclusions}

In summary, we found that the $\mathrm{Cu}$ surface with oxidation state distribution changes the $\mathrm{CO}_{2}$ reduction mechanism. The electrodeposited $\mathrm{Cu}$ electrode shows more $\mathrm{Cu}(\mathrm{I})$. 
The $\mathrm{CO}_{\text {atop }}$ intermediate species is formed on the surface and the formation of $\mathrm{C}_{1}$ hydrocarbon product is obtained during further reduction. As-prepared $\mathrm{Cu}$ electrode exhibits the oxidation state of $\mathrm{Cu}(0)$. The $\mathrm{CO}_{\text {bridge }}$ is formed on the surface and inhibits the formation of hydrocarbon product. In contrast, the $\mathrm{CV}$-treated $\mathrm{Cu}$ electrode shows the coexistence of $\mathrm{Cu}(\mathrm{I})$ and $\mathrm{Cu}(0)$ and forms both $\mathrm{CO}_{\text {atop }}$ and $\mathrm{CO}_{\text {bridge }}$ during $\mathrm{CO}_{2}$ reduction. The enhanced $\mathrm{C}_{2}$ product selectivity is also obtained. Thus, oxidation state of $\mathrm{Cu}$ catalysts affects the electrocatalytic properties of interface and modulates the $\mathrm{CO}_{2}$ reduction mechanism. Our findings provide a strategy for designing more selective $\mathrm{Cu}$ electrocatalysts for electrochemical $\mathrm{CO}_{2}$ reduction.

\section{ASSOCIATED CONTENT}

\section{Supporting Information.}

AFM images of as-prepared $\mathrm{Cu}$ and the cross section profile of as-prepared $\mathrm{Cu}$ (Figure S1). AFM image and CV of electrodeposited Cu electrode (Figure S2). Cell configuration of in situ SEIRAS measurements (Figure S3). Cell configuration of in situ soft XAS measurements (Figure S4). Cell configuration of on-line GC measurements (Figure S5). Double layer capacitances of as-prepared $\mathrm{Cu}$ electrode and CV-treated $\mathrm{Cu}$ electrode (Figure S6). EXAFS spectra of pristine as-prepared, CV- 
treated and electrodeposited $\mathrm{Cu}$ electrodes (Figure S7). $\mathrm{Cu} \mathrm{L}_{3}$-edge XAS of standard $\mathrm{Cu}$ electrodes in TFY mode (Figure S8). In situ SEIRA spectra of electrodeposited $\mathrm{Cu}$ electrode, as-prepared $\mathrm{Cu}$ electrode and $\mathrm{CV}$-treated $\mathrm{Cu}$ electrode (Figure $\mathrm{S} 9$ ). In situ SEIRA spectra of $\mathrm{CV}$-treated $\mathrm{Cu}$ electrode obtained at $-1 \mathrm{~V}$ and without applied potential (Figure S10). AFM image of the surface morphology of $\mathrm{CV}$-treated $\mathrm{Cu}$ electrode (after $100 \mathrm{CV}$-treated cycles) (Figure S11). FEs of major products catalyzed by CV-treated Cu electrode (after 3, 10 and $30 \mathrm{CV}$-treated cycles) at -1 V (Figure S12). AFM images of the surface morphology of (a) CV-treated Cu electrode (3 CV-treated cycles) and (b) CV-treated $\mathrm{Cu}$ electrode (100 CV-treated cycles) after holding the potential at $-1 \mathrm{~V}$ for $60 \mathrm{~min}$ in the $\mathrm{CO}_{2}$ saturated $0.1 \mathrm{M} \mathrm{KHCO}_{3}$ electrolyte (Figure S13). FEs of methane and ethylene catalyzed by $\mathrm{CV}$-treated $\mathrm{Cu}$ electrode (after three $\mathrm{CV}$ treated cycles) after holding the potential at $-1 \mathrm{~V}$ in $\mathrm{CO}_{2}$ saturated $0.1 \mathrm{M} \mathrm{KHCO}_{3}$ electrolyte. (Figure S14). This material is available free of charge via the Internet at http://pubs.acs.org.

\section{AUTHOR INFORMATION}

\section{Corresponding Authors}

*Email: hengliangwu@ntu.edu.tw

Telephone: $+886-2-33665260$ 


\section{Notes}

The authors declare no competing financial interest.

\section{Acknowledgments}

This research was funded by MOST (Ministry of Science and Technology), Taiwan. (107-2113-M-002 -014 -MY2) We thank Prof. Tsan-Yao Chen in Department of Engineering and System Science, National Tsing Hua University and Prof. KuanWen Wang in Institute of Materials Science and Engineering, National Central University for the technical support. We thank Ms. Po-Yu Su in Center for Condensed Matter Sciences, National Taiwan University for the gas product measurements. We thank financial support from the Center of Atomic Initiative for New Materials, National Taiwan University, from the Featured Areas Research Center Program within the framework of the Higher Education Sprout Project by the Ministry of Education in Taiwan (108L9008).

\section{References}

1. Seh, Z. W.; Kibsgaard, J.; Dickens, C. F.; Chorkendorff, I. B.; Norskov, J. K.; Jaramillo, T. F., Combining theory and experiment in electrocatalysis: Insights into materials design. Science 2017, 355, eaad4998.

2. Zhu, D. D.; Liu, J. L.; Qiao, S. Z., Recent Advances in Inorganic Heterogeneous Electrocatalysts for Reduction of Carbon Dioxide. Adv. Mater. 2016, 28, 3423.

3. Kas, R.; Kortlever, R.; Milbrat, A.; Koper, M. T. M.; Mul, G.; Baltrusaitis, J., Electrochemical $\mathrm{CO}_{2}$ reduction on $\mathrm{Cu}_{2} \mathrm{O}$-derived copper nanoparticles: controlling the 
catalytic selectivity of hydrocarbons. PCCP 2014, 16, 12194.

4. Gao, D. F.; Aran-Ais, R. M.; Jeon, H. S.; Cuenya, B. R., Rational catalyst and electrolyte design for $\mathrm{CO}_{2}$ electroreduction towards multicarbon products. Nat. Catal. 2019, 2, 198.

5. Khezri, B.; Fisher, A. C.; Pumera, M., $\mathrm{CO}_{2}$ reduction: the quest for electrocatalytic materials. J. Mater. Chem. A 2017, 5, 8230.

6. Zheng, Y.; Vasileff, A.; Zhou, X. L.; Jiao, Y.; Jaroniec, M.; Qiao, S. Z., Understanding the Roadmap for Electrochemical Reduction of $\mathrm{CO}_{2}$ to Multi-Carbon Oxygenates and Hydrocarbons on Copper-Based Catalysts. J. Am. Chem. Soc. 2019, $141,7646$.

7. Takahashi, I.; Koga, O.; Hoshi, N.; Hori, Y., Electrochemical reduction of $\mathrm{CO}_{2}$ at copper single crystal $\mathrm{Cu}(\mathrm{S})-[\mathrm{n}(111) \times(111)]$ and $\mathrm{Cu}(\mathrm{S})-[\mathrm{n}(110) \times(100)]$ electrodes. $J$. Electroanal. Chem. 2002, 533, 135.

8. Hori, Y.; Takahashi, I.; Koga, O.; Hoshi, N., Electrochemical reduction of carbon dioxide at various series of copper single crystal electrodes. J. Mol. Catal. A: Chem. 2003, 199, 39.

9. Reske, R.; Mistry, H.; Behafarid, F.; Roldan Cuenya, B.; Strasser, P., Particle Size Effects in the Catalytic Electroreduction of $\mathrm{CO}_{2}$ on $\mathrm{Cu}$ Nanoparticles. J. Am. Chem. Soc. 2014, 136, 6978.

10. Cheng, T.; Xiao, H.; Goddard, W. A., Nature of the Active Sites for CO Reduction on Copper Nanoparticles; Suggestions for Optimizing Performance. J. Am. Chem. Soc. 2017, 139, 11642.

11. Kim, J.; Choi, W.; Park, J. W.; Kim, C.; Kim, M.; Song, H., Branched Copper Oxide Nanoparticles Induce Highly Selective Ethylene Production by Electrochemical Carbon Dioxide Reduction. J. Am. Chem. Soc. 2019, 141, 6986.

12. Jung, H.; Lee, S. Y.; Lee, C. W.; Cho, M. K.; Won, D. H.; Kim, C.; Oh, H. S.; Min, B. K.; Hwang, Y. J., Electrochemical Fragmentation of $\mathrm{Cu}_{2} \mathrm{O}$ Nanoparticles Enhancing Selective C-C Coupling from $\mathrm{CO}_{2}$ Reduction Reaction. J. Am. Chem. Soc. 2019, 141, 4624.

13. Gao, D. F.; Zegkinoglou, I.; Divins, N. J.; Scholten, F.; Sinev, I.; Grosse, P.; Roldan Cuenya, B., Plasma-Activated Copper Nanocube Catalysts for Efficient Carbon Dioxide Electroreduction to Hydrocarbons and Alcohols. ACS Nano 2017, 11, 4825.

14. Scholten, F.; Sinev, I.; Bernal, M.; Cuenya, B. R., Plasma-Modified Dendritic Cu Catalyst for $\mathrm{CO}_{2}$ Electroreduction. ACS Catal. 2019, 9, 5496.

15. Eilert, A.; Cavalca, F.; Roberts, F. S.; Osterwalder, J.; Liu, C.; Favaro, M.; Crumlin, E. J.; Ogasawara, H.; Friebel, D.; Pettersson, L. G. M.; Nilsson, A., Subsurface Oxygen in Oxide-Derived Copper Electrocatalysts for Carbon Dioxide Reduction. J. Phys. Chem. Lett. 2017, 8, 285. 
16. Dinh, C. T.; Burdyny, T.; Kibria, M. G.; Seifitokaldani, A.; Gabardo, C. M.; de Arquer, F. P. G.; Kiani, A.; Edwards, J. P.; De Luna, P.; Bushuyev, O. S.; Zou, C. Q.; Quintero-Bermudez, R.; Pang, Y. J.; Sinton, D.; Sargent, E. H., $\mathrm{CO}_{2}$ electroreduction to ethylene via hydroxide-mediated copper catalysis at an abrupt interface. Science 2018, $360,783$.

17. Favaro, M.; Xiao, H.; Cheng, T.; Goddard, W. A.; Yano, J.; Crumlin, E. J., Subsurface oxide plays a critical role in $\mathrm{CO}_{2}$ activation by $\mathrm{Cu}(111)$ surfaces to form chemisorbed $\mathrm{CO}_{2}$, the first step in reduction of $\mathrm{CO}_{2}$. Proc. Natl. Acad. Sci. U.S.A. 2017, 114, 6706 .

18. Mistry, H.; Varela, A. S.; Bonifacio, C. S.; Zegkinoglou, I.; Sinev, I.; Choi, Y. W.; Kisslinger, K.; Stach, E. A.; Yang, J. C.; Strasser, P.; Cuenya, B. R., Highly selective plasma-activated copper catalysts for carbon dioxide reduction to ethylene. Nat. Comm. 2016, 7, 12123.

19. Li, C. W.; Kanan, M. W., $\mathrm{CO}_{2}$ Reduction at Low Overpotential on $\mathrm{Cu}$ Electrodes Resulting from the Reduction of Thick $\mathrm{Cu}_{2} \mathrm{O}$ Films. J. Am. Chem. Soc. 2012, 134, 7231. 20. Eilert, A.; Roberts, F. S.; Friebel, D.; Nilsson, A., Formation of Copper Catalysts for $\mathrm{CO}_{2}$ Reduction with High Ethylene/Methane Product Ratio Investigated with In Situ X-ray Absorption Spectroscopy. J. Phys. Chem. Lett. 2016, 7, 1466.

21. Mariano, R. G.; McKelvey, K.; White, H. S.; Kanan, M. W., Selective increase in $\mathrm{CO}_{2}$ electroreduction activity at grain-boundary surface terminations. Science 2017, $358,1187$.

22. Feng, X. F.; Jiang, K. L.; Fan, S. S.; Kanan, M. W., Grain-Boundary-Dependent $\mathrm{CO}_{2}$ Electroreduction Activity. J. Am. Chem. Soc. 2015, 137, 4606.

23. Xiao, H.; Goddard, W. A.; Cheng, T.; Liu, Y. Y., Cu metal embedded in oxidized matrix catalyst to promote $\mathrm{CO}_{2}$ activation and $\mathrm{CO}$ dimerization for electrochemical reduction of $\mathrm{CO}_{2}$. Proc. Natl. Acad. Sci. U.S.A. 2017, 114, 6685.

24. Heyes, J.; Dunwell, M.; Xu, B. J., $\mathrm{CO}_{2}$ Reduction on $\mathrm{Cu}$ at Low Overpotentials with Surface-Enhanced in Situ Spectroscopy. J. Phys. Chem. C 2016, 120, 17334.

25. Wuttig, A.; Liu, C.; Peng, Q. L.; Yaguchi, M.; Hendon, C. H.; Motobayashi, K.; Ye, S.; Osawa, M.; Surendranath, Y., Tracking a Common Surface-Bound Intermediate during $\mathrm{CO}_{2}$-to-Fuels Catalysis. ACS Cent. Sci. 2016, 2, 522.

26. Zhu, S. Q.; Jiang, B.; Cai, W. B.; Shao, M. H., Direct Observation on Reaction Intermediates and the Role of Bicarbonate Anions in $\mathrm{CO}_{2}$ Electrochemical Reduction Reaction on Cu Surfaces. J. Am. Chem. Soc. 2017, 139, 15664.

27. Gunathunge, C. M.; Ovalle, V. J.; Li, Y. W.; Janik, M. J.; Waegele, M. M., Existence of an Electrochemically Inert $\mathrm{CO}$ Population on $\mathrm{Cu}$ Electrodes in Alkaline pH. ACS Catal. 2018, 8, 7507.

28. Malkani, A. S.; Dunwell, M.; Xu, B. J., Operando Spectroscopic Investigations of 
Copper and Oxide Derived Copper Catalysts for Electrochemical CO Reduction. ACS Catal. 2019, 9, 474.

29. Hayden, B. E.; Kretzschmar, K.; Bradshaw, A. M., An Infrared Spectroscopic Study of $\mathrm{CO}$ on $\mathrm{Cu}(111)$ - the Linear, Bridging and Physisorbed Species. Surf. Sci. 1985, $155,553$.

30. Salimon, J.; Hernandez-Romero, R. M.; Kalaji, M., The dynamics of the conversion of linear to bridge bonded $\mathrm{CO}$ on Cu. J. Electroanal. Chem. 2002, 538, 99. 31. Ooka, H.; Figueiredo, M. C.; Koper, M. T. M., Competition between Hydrogen Evolution and Carbon Dioxide Reduction on Copper Electrodes in Mildly Acidic Media. Langmuir 2017, 33, 9307.

32. Wang, H. F.; Yan, Y. G.; Hu, S. J.; Cai, W. B.; Xu, Q. H.; Osawa, M., Seeded growth fabrication of $\mathrm{Cu}$-on-Si electrodes for in situ ATR-SEIRAS applications. Electrochim. Acta 2007, 52, 5950.

33. Lee, S.; Lee, J., Ethylene Selectivity in $\mathrm{CO}$ Electroreduction when using $\mathrm{Cu}$ Oxides: An In Situ ATR-SEIRAS Study. ChemElectroChem 2018, 5, 558.

34. Yaguchi, M.; Uchida, T.; Motobayashi, K.; Osawa, M., Speciation of Adsorbed Phosphate at Gold Electrodes: A Combined Surface-Enhanced Infrared Absorption Spectroscopy and DFT Study. J. Phys. Chem. Lett. 2016, 7, 3097.

35. Ataka, K.; Yotsuyanagi, T.; Osawa, M., Potential-dependent reorientation of water molecules at an electrode/electrolyte interface studied by surface-enhanced infrared absorption spectroscopy. J. Phys. Chem. 1996, 100, 10664.

36. Chen, Y. X.; Miki, A.; Ye, S.; Sakai, H.; Osawa, M., Formate, an active intermediate for direct oxidation of methanol on Pt electrode. J. Am. Chem. Soc. 2003, 125,3680 .

37. Velasco-Velez, J. J.; Jones, T.; Gao, D.; Carbonio, E.; Arrigo, R.; Hsu, C. J.; Huang, Y. C.; Dong, C. L.; Chen, J. M.; Lee, J. F.; Strasser, P.; Cuenya, B. R.; Schlog, R.; KnopGericke, A.; Chuang, C. H., The Role of the Copper Oxidation State in the Electrocatalytic Reduction of $\mathrm{CO}_{2}$ into Valuable Hydrocarbons. ACS Sustain. Chem. Eng. 2019, 7, 1485.

38. Degroot, F. M. F., X-Ray-Absorption and Dichroism of Transition-Metals and Their Compounds. J. Electron. Spectrosc. Relat. Phenom. 1994, 67, 529.

39. Achkar, A. J.; Regier, T. Z.; Wadati, H.; Kim, Y. J.; Zhang, H.; Hawthorn, D. G., Bulk sensitive X-ray absorption spectroscopy free of self-absorption effects. Phys. Rev. $B$ 2011, 83, 081106.

40. Velasco-Velez, J. J.; Skorupska, K.; Frei, E.; Huang, Y. C.; Dong, C. L.; Su, B. J.; Hsu, C. J.; Chou, H. Y.; Chen, J. M.; Strasser, P.; Schlogl, R.; Knop-Gericke, A.; Chuang, C. H., The Electro-Deposition/Dissolution of $\mathrm{CuSO}_{4}$ Aqueous Electrolyte Investigated by In Situ Soft X-ray Absorption Spectroscopy. J. Phys. Chem. B 2018, 122, 780. 
41. Lien, H. T.; Wong, D. P.; Tsao, N. H.; Huang, C. I.; Su, C. C.; Chen, K. H.; Chen, L. C., Effect of Copper Oxide Oxidation State on the Polymer-Based Solar Cell Buffer Layers. ACS Appl. Mater. Inter. 2014, 6, 22445.

42. Hollmark, H. M.; Vegelius, J. R.; Kristiansen, P.; Werme, L.; Duda, L. C., Exposure of Oxidized Copper Surfaces to Aqueous $\mathrm{Na}_{2} \mathrm{~S}$ Solution Studied with Soft XRay Spectroscopy. J. Electrochem. Soc. 2011, 158, C1.

43. Stern, E. A.; Kim, K., Thickness Effect on the Extended-X-Ray-Absorption-FineStructure Amplitude. Phys. Rev. B 1981, 23, 3781.

44. Wang, X. T.; Martin, N. M.; Nilsson, J.; Carlson, S.; Gustafson, J.; Skoglundh, M.; Carlsson, P. A., Copper-Modified Zeolites and Silica for Conversion of Methane to Methanol. Catalysts 2018, 8, 545.

45. Weng, Z.; Wu, Y. S.; Wang, M. Y.; Jiang, J. B.; Yang, K.; Huo, S. J.; Wang, X. F.; Ma, Q.; Brudvig, G. W.; Batista, V. S.; Liang, Y. Y.; Feng, Z. X.; Wang, H. L., Active sites of copper-complex catalytic materials for electrochemical carbon dioxide reduction. Nat. Comm. 2018, 9, 415.

46. Ruosi, A.; Raisch, C.; Verna, A.; Werner, R.; Davidson, B. A.; Fujii, J.; Kleiner, R.; Koelle, D., Electron sampling depth and saturation effects in perovskite films investigated by soft x-ray absorption spectroscopy. Phys. Rev. B 2014, 90, 125120.

47. Gunathunge, C. M.; Li, X.; Li, J. Y.; Hicks, R. P.; Ovalle, V. J.; Waegele, M. M., Spectroscopic Observation of Reversible Surface Reconstruction of Copper Electrodes under $\mathrm{CO}_{2}$ Reduction. J. Phys. Chem. C 2017, 121, 12337.

48. Sun, S. G.; Cai, W. B.; Wan, L. J.; Osawa, M., Infrared absorption enhancement for $\mathrm{CO}$ adsorbed on $\mathrm{Au}$ films in perchloric acid solutions and effects of surface structure studied by cyclic voltammetry, scanning tunneling microscopy, and surface-enhanced IR spectroscopy. J. Phys. Chem. B 1999, 103, 2460.

49. Samjeske, G.; Komatsu, K.; Osawa, M., Dynamics of CO Oxidation on a Polycrystalline Platinum Electrode: A Time-Resolved Infrared Study. J. Phys. Chem. C 2009, 113, 10222.

50. Iwasita, T.; Nart, F. C.; Lopez, B.; Vielstich, W., On the Study of Adsorbed Species at Platinum from Methanol, Formic-Acid and Reduced Carbon-Dioxide Via Insitu FtIr Spectroscopy. Electrochim. Acta 1992, 37, 2361.

51. Figueiredo, M. C.; Ledezma-Yanez, I.; Koper, M. T. M., In Situ Spectroscopic Study of $\mathrm{CO}_{2}$ Electroreduction at Copper Electrodes in Acetonitrile. ACS Catal. 2016, 6, 2382.

52. Osawa, M.; Ataka, K.; Yoshii, K.; Nishikawa, Y., Surface-Enhanced InfraredSpectroscopy - The Origin of the Absorption Enhancement and Band Selection Rule in the Infrared-Spectra of Molecules Adsorbed on Fine Metal Particles. Appl. Spectrosc. 1993, 47, 1497. 
53. Lee, S. J.; Han, S. W.; Yoon, M.; Kim, K., Adsorption characteristics of 4dimethylaminobenzoic acid on silver and titania: Diffuse reflectance infrared Fourier transform spectroscopy study. Vib. Spectrosc. 2000, 24, 265.

54. Firet, N. J.; Smith, W. A., Probing the Reaction Mechanism of $\mathrm{CO}_{2}$ Electroreduction over Ag Films via Operando Infrared Spectroscopy. ACS Catal. 2017, 7, 606 .

55. Kim, Y. G.; Baricuatro, J. H.; Javier, A.; Gregoire, J. M.; Soriaga, M. P., The Evolution of the Polycrystalline Copper Surface, First to $\mathrm{Cu}(111)$ and Then to $\mathrm{Cu}(100)$, at a Fixed $\mathrm{CO}_{2}$ RR Potential: A Study by Operand EC-STM. Langmuir 2014, 30, 15053. 56. Kim, Y.-G.; Baricuatro, J. H.; Soriaga, M. P., Surface Reconstruction of Polycrystalline $\mathrm{Cu}$ Electrodes in Aqueous $\mathrm{KHCO} 3$ Electrolyte at Potentials in the Early Stages of CO2 Reduction. Electrocatalysis 2018, 9, 526.

57. Huang, Y.; Handoko, A. D.; Hirunsit, P.; Yeo, B. S., Electrochemical Reduction of CO2 Using Copper Single-Crystal Surfaces: Effects of CO* Coverage on the Selective Formation of Ethylene. ACS Catal. 2017, 7, 1749.

58. Schouten, K. J.; Qin, Z.; Perez Gallent, E.; Koper, M. T., Two pathways for the formation of ethylene in $\mathrm{CO}$ reduction on single-crystal copper electrodes. J. Am. Chem. Soc. 2012, 134, 9864.

\section{Table of Contents (TOC) graphic}

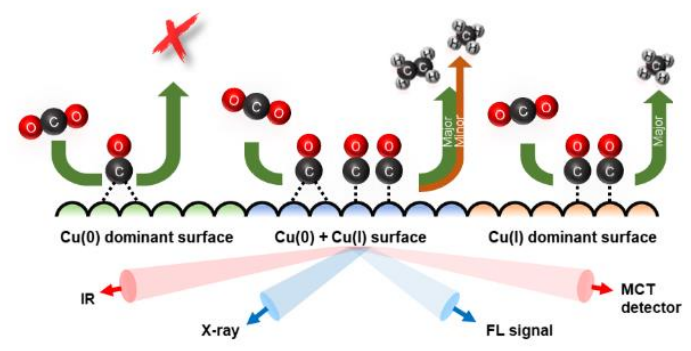

"For Table of Contents Only" 